\title{
Retinol-Binding Protein: the Transport Protein for Vitamin A in Human Plasma
}

\author{
Masamitsu Kanai, Amuram Raz, and DeWitt S. Goodman \\ From the Department of Medicine, Columbia University College of Physicians \\ and Surgeons, New York 10032
}

A в S T R A C T Vitamin A circulates in human plasma as retinol bound to a specific transport protein. This protein differs from the known low and high density plasma lipoproteins and has a hydrated density greater than 1.21 . In order to study this protein, volunteers were injected intravenously with retinol-15-14 C. Plasma was collected 1-3 days later, and the purification of retinol-binding protein (RBP) was monitored by assaying for ${ }^{14} \mathrm{C}$ and also by following the fluorescence of the proteinbound retinol. Purification of RBP was effected by the sequence: Cohn fractionation, chromatography on columns of Sephadex G-200 and diethylaminoethyl (DEAE)-Sephadex, preparative polyacrylamide gel electrophoresis, and finally chromatography on Sephadex G-100. These procedures resulted in a preparation of RBP which was at least 98\% pure and which had been purified more than 1500 -fold. Purified RBP has $\alpha_{1}$ mobility on electrophoresis and has a molecular weight of approximately $21,000-22,000$. There appears to be one binding site for retinol per molecule of RBP. Solutions of RBP are fluorescent (characteristic of retinol) and have ultraviolet absorption spectra with peaks at $330 \mathrm{~m} \mu$ (resulting from the bound retinol) and at $280 \mathrm{~m} \mu$. There are no fatty acid or

This paper is No. 8 in the series "Vitamin A and carotenoids" from the laboratory of DeW. S. Goodman. An abstract of this work was presented to the Seventh International Congress of Biochemistry in Tokyo, Japan, in August 1967 (39), and the work was presented, in part, at the 11th International Conference on the Biochemistry of Lipids, Jerusalem, Israel, August 1967, and at the 1968 annual meeting of the American Society for Biological Chemists (40).

Masamitsu Kanai's permanent address is Shinshu University Hospital, Matsumoto City, Japan.

Received for publication 6 February 1968. fatty acyl chains present in purified RBP. The usual concentration of RBP in plasma is of the order of $3-4 \mathrm{mg} / 100 \mathrm{ml}$. In plasma, RBP apparently circulates as a complex, together with another, larger protein with prealbumin mobility on electrophoresis. The RBP-prealbumin complex remains intact during Cohn fractionation and during chromatography on Sephadex and on DEAESephadex columns. The complex dissociates during gel electrophoresis, permitting the isolation and subsequent purification of each of the components. The complex is again formed by mixing together solutions of the separated RBP and of prealbumin. Retinol transport in plasma thus appears to involve both a lipid-protein (retinol$\mathrm{RBP}$ ) interaction and a protein-protein (RBPprealbumin) interaction.

\section{INTRODUCTION}

It is well established that vitamin A mainly circulates in plasma as retinol (vitamin A alcohol), apparently associated with a transport protein of hydrated density greater than $1.21(1-3)$. This protein differs from serum albumin in man (1) and has been reported to have $\alpha_{1}$ mobility (2) or $\alpha_{2}$ mobility (4) in the rat. Recently, Alvsaker, Haugli, and Laland (5) have suggested that this protein is identical with the tryptophane-rich prealbumin in human serum. Detailed information about the transport of retinol in plasma is, however, not available. We now report the purification and partial characterization of retinol-binding protein ( $R B P$ ), the specific protein to which retinol is bound in human plasma. RBP has $\alpha_{1}$ mobility and differs from all previously identified plasma proteins. 


\section{METHODS}

Plasma. The studies reported here were carried out with fresh blood, collected in acid citrate dextrose (ACD) anticoagulant, from healthy young adult donors. The isolation of RBP was carried out three times: first with $280 \mathrm{ml}$ of plasma from one donor, second with $1700 \mathrm{ml}$ of plasma from six donors, and third with 5 liters of plasma from 16 donors. The plasma used in the first of these preparations, and $300 \mathrm{ml}$ of the plasma used in the second preparation, was derived from subjects previously injected with ${ }^{14} \mathrm{C}$-labeled retinol.

Assay. The purification of RBP was quantitatively monitored by assaying the fractions from each purification procedure for protein-bound retinol. In the initial stages of this work this assay was carried out by the extraction of plasma or plasma fractions with $\mathrm{CHCl}_{3}$ $\mathrm{CH}_{3} \mathrm{OH}, 2: 1(\mathrm{v} / \mathrm{v})$, followed by the chromatography of the total lipid extracts on small columns of deactivated alumina (6) in order to isolate retinol. The retinol was then assayed spectrophotometrically (in our laboratory $E_{1 \mathrm{~cm}}^{1 \%}=1625$ at $330 \mathrm{~m} \mu$ for retinol in benzene). During most of this work, however, a simpler assay was used, in which the protein-bound retinol was first labeled with ${ }^{14} \mathrm{C}$, and the purification of RBP was then monitored by radioassay, for ${ }^{14} \mathrm{C}$, of the total lipid extracts. To this end, normal volunteers were injected intravenously with retinol-15- ${ }^{14} \mathrm{C}$ dispersed in their own plasma. The dispersion was achieved by adding, via a microsyringe and under sterile conditions, $0.5 \mathrm{ml}$ of acetone containing $12 \mu \mathrm{c}$ of retinol $-15-{ }^{14} \mathrm{C}$ (specific radioactivity 29.6 $\mu \mathrm{c} / \mathrm{mg}$ ) to $20 \mathrm{ml}$ of freshly collected plasma. Plasma was collected 1-3 days after ${ }^{14} \mathrm{C}$-retinol injection and was used for RBP purification. The radioactivity $\left({ }^{14} \mathrm{C}\right)$ in these plasma samples was shown by extraction and chromatography to reside almost entirely in retinol. The ${ }^{14} \mathrm{C}$ assay procedure for protein-bound retinol was validated for each purification method by showing that comparable results were obtained by ${ }^{14} \mathrm{C}$ assay and by spectrophotometric assay for retinol. In addition, RBP purification was also qualitatively monitored by observing under ultraviolet light the visible, green fluorescence of proteinbound retinol.

Chromatography. Gel filtration (7) was carried out with columns of Sephadex ${ }^{1}$ G-100 or G-200, with phosphate buffer, usually at $\mathrm{pH} 7.4$ or 7.6, and containing 0.2 M $\mathrm{NaCl}$. Ion-exchange chromatography was conducted with columns of DEAE-Sephadex ${ }^{1}$ A-50, with phos-

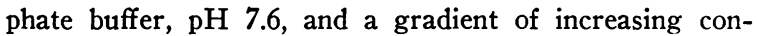
centration of $\mathrm{NaCl}$. Specific details for these procedures are provided for representative examples in the legends to the figures. All column chromatography was carried out in a cold room at $4^{\circ}-5^{\circ} \mathrm{C}$.

Electrophoresis. Analytical and preparative polyacrylamide gel electrophoresis were performed in $7 \%$ acrylamide gel without a concentrating gel, with a continuous buffer system of Tris-glycine- $\mathrm{HCl}, \mathrm{pH} 8.1$, under conditions similar to those described by Nerenberg (8). Analytical disc gel electrophoresis employed a current

1 Pharmacia Fine Chemicals, Inc., Piscataway, N. J. of 1 mamp per tube at room temperature and was terminated just when the tracking dye ran out of the gel. For preparative purposes, the Buchler ${ }^{2}$ "polyprep" apparatus was used in a manner similar to that described by Jovin, Chrambach, and Naughton (9). The prepared gel column, about $9.5 \mathrm{~cm}$ high, was prerun for $1 \mathrm{hr}$ at 30 mamps before the sample was applied. In the usual procedure, carried out at $2^{\circ}-5^{\circ} \mathrm{C}$, a sample of $30-60 \mathrm{mg}$ of protein was dissolved in $4.5 \mathrm{ml}$ of upper buffer, $0.5 \mathrm{ml}$ of $40 \%$ sucrose solution was added, and the mixed sample was then applied to the top of the gel. Electrophoresis was begun at a current of 15-20 mamps. After $30 \mathrm{~min}$ the current was adjusted to 30-35 mamps and was maintained at this level until the voltage reached 500 volts, after which time electrophoresis was continued at a constant voltage of 500 volts. The elution rate was $30-40$ $\mathrm{ml} / \mathrm{hr}$. The complete procedure usually required $8-10 \mathrm{hr}$ time. During gel electrophoresis the effluent stream was monitored continuously for absorption of light at wavelength $280 \mathrm{~m} \mu .^{3}$ The effluent stream from most column chromatographic runs was similarly monitored.

Paper electrophoresis was performed in glycine-acetate buffer, $\mathrm{pH} 8.6$, ionic strength 0.15 (10). Zone electrophoresis on Pevikon was kindly performed by $\mathrm{Dr}$. Jane $\mathrm{H}$. Morse, with barbital buffer, $\mathrm{pH}$ 8.6, ionic strength 0.1 (11). At the end of electrophoresis, $1 \mathrm{~cm}$ strips of Pevikon were collected and eluted. The eluates were analyzed for protein and for ${ }^{14} \mathrm{C}$ (after $\mathrm{CHCl}_{3}$ $\mathrm{CH}_{3} \mathrm{OH}$ extraction).

Analytical ultracentrifugation. Sedimentation equilibrium and velocity analyses were kindly carried out by Dr. Herbert S. Rosenkranz in a Spinco model E ultracentrifuge. The molecular weight of RBP was estimated by the sedimentation equilibrium (Archibald) method as described by Schachman (12). Analyses were carried out on a solution of $10 \mathrm{mg}$ of RBP per $\mathrm{ml}$ in $0.05 \mathrm{M}$ potassium phosphate buffer, $\mathrm{pH}$ 7.2. Centrifugation was conducted at $10.6^{\circ} \mathrm{C}$ at two speeds (9341 and $15,220 \mathrm{rpm}$ ), and photographs were taken with Schlieren optics. Photographs taken at each speed at bar angles of 70 and of $80^{\circ}$ were measured in a microcomparator, together with photographs taken from a run in a synthetic boundary cell. Calculations were made only from the measurements at the top of the cell, since some denaturation apparently occurred at the oil-water interface at the bottom of the cell. The molecular weight was calculated as described by Schachman (12), using an assumed value of 0.75 as an estimate for the term $\overline{\mathrm{V}} \rho$. This value is close to the value of $\overline{\mathrm{V}} \rho(0.73)$ which can be calculated from the amino acid composition, the partial molal volume for each amino acid, and the measured density of the solution. It is hence felt that the assumed value for $\bar{V} \rho$ did not introduce any major error in the estimation of the molecular weight. It should, however, be noted that the calculated molecular weight is only an approximate estimate, because of the uncertainty in the value of $\overline{\mathrm{V}} \rho$.

2 Buchler Instruments, Inc., Fort Lee, N. J.

3 Uvicord II absorptiometer, LKB Instruments, Inc., Rockville, Md. 
Sedimentation velocity studies were carried out on a solution of $1 \mathrm{mg} / \mathrm{ml}$ in the same buffer, using ultraviolet absorption optics. The sedimentation coefficient was calculated for a solution of this protein concentration in water at $20^{\circ} \mathrm{C}\left(s_{20, w}\right)$.

Amino acid analysis. The amino acid composition of RBP was kindly determined by Dr. Robert E. Canfield. Equal-sized portions (about $0.5 \mathrm{mg}$ each) of RBP were each dissolved in $1 \mathrm{ml}$ of constant boiling $\mathrm{HCl}$ and hydrolyzed in evacuated sealed tubes kept at $108^{\circ} \pm 1^{\circ} \mathrm{C}$ for 24,48 , or $72 \mathrm{hr}$. The $\mathrm{HCl}$ was removed by evaporation in vacuo over $\mathrm{KOH}$. Amino acid analyses were performed by the method of Spackman, Stein, and Moore (13) on a Spinco Model 120B amino acid analyzer. No attempts were made to determine the $1 / 2$ cystine content after oxidation or reduction and alkylation of RBP.

The tryptophane content of RBP was estimated by determining the ratio of tyrosine to tryptophane by the method of Goodwin and Morton (14). Purified apo-RBP (preparation $\mathrm{RBP}_{\mathrm{a}}$, see Results), $0.87 \mathrm{mg}$, was dissolved in $1.0 \mathrm{ml} 0.1 \mathrm{~N} \mathrm{NaOH}$ and the absorption spectrum measured in a Cary model 14 spectrophotometer. A base line of "irrelevant absorption" was obtained by extrapolating the absorption between $360 \mathrm{~m} \mu$ and $340 \mathrm{~m} \mu$ back to 260 $\mathrm{m} \mu$. The corresponding base line values were subtracted from the absorbances observed at $280 \mathrm{~m} \mu$ and at 294.4 $\mathrm{m} \mu$ and the ratio of tyrosine to tryptophane then calculated as described (14).

Other procedures. Double diffusion in gel was performed by the method of Ouchterlony (15), with gels made of $0.7 \%$ agar in $\mathrm{Na}$ barbiturate-glycine buffer, $\mathrm{pH}$ 7.6.

Cohn fractionation was carried out according to method 10 of Cohn et al. (16). In early studies, whole plasma (ACD anticoagulant) was used for Cohn fractionation. In later work, fibrinogen (Cohn Fraction I) was first removed from the plasma by addition of $3 U$ of bovine thrombin 4 per $\mathrm{ml}$ of plasma. The plasma was incubated for $2 \mathrm{hr}$ at room temperature with stirring and the insoluble fibrin removed by filtration.

The distribution of retinol among the different plasma lipoproteins was determined on a sample of plasma collected from a subject 27 days after the intravenous injection of retinol-1" $\mathrm{C}$. It was assumed that considerable equilibration would have occurred by this time between the injected labeled retinol and the body pools of vitamin A. A portion of the plasma was extracted and the lipid extract chromatographed on deactivated alumina (6). Almost all (94\%) of the ${ }^{14} \mathrm{C}$ applied to the column was recovered after chromatography; $88 \%$ of the recovered radioactivity was found in the retinol fraction. These results are virtually identical with those obtained in our laboratory for the extraction and chromatography of pure retinol, and establish that the ${ }^{14} \mathrm{C}$ in plasma was present in retinol. Another portion of the plasma was separated into lipoprotein classes of density less than 1.063 , between 1.063 and 1.21 , and greater than 1.21 , by the method of Havel, Eder, and Bragdon (17).

\footnotetext{
4 Parke Davis \& Company, Detroit, Mich.
}

The lipoprotein fractions were not washed by recentrifugation. Each of the fractions was extracted, and the lipid extracts were chromatographed on alumina. The retinol fractions were collected and assayed for radioactivity.

Protein concentrations were determined by the method of Lowry, Rosebrough, Farr, and Randall (18), with crystalline bovine serum albumin as a standard.

Radioassay was carried out by dissolving samples in 15 $\mathrm{ml}$ of $0.5 \%$ diphenyloxazole in toluene, followed by assay with a Packard Tri-Carb liquid scintillation counter. Significant quenching was not observed.

Absorption spectra and absorbances were usually measured with a Beckman DB spectrophotometer. In some instances spectra were recorded with a Cary model 14 spectrophotometer.

The content of retinol in purified RBP preparations was determined by extracting $1 \mathrm{ml}$ of $\mathrm{RBP}$ solution, together with $1 \mathrm{ml}$ of freshly drawn plasma, with 20 volumes of $\mathrm{CHCl}_{3}-\mathrm{CH}_{3} \mathrm{OH}(2: 1)$ in the usual way. After evaporation of the chloroform, the lipid residue was chromatographed on $2 \mathrm{~g}$ of deactivated alumina (6) ; the retinol fraction was evaporated to dryness and the residue dissolved in $1 \mathrm{ml}$ of benzene. The benzene solution was then analyzed spectrophotometrically. Control samples of $1 \mathrm{ml}$ of plasma alone were processed in the same manner and the ultraviolet absorption of the corresponding column fraction subtracted from that of the RBP sample. The plasma was added before extraction in order to protect the retinol against oxidative loss during the procedure. For a series of eight standard samples, in which small measured amounts of retinol (not RBP) were added to the $\mathrm{CHCl}_{3}-\mathrm{CH}_{3} \mathrm{OH}$ extracts, the recovery of retinol (assayed spectrophotometrically) was $89.9 \pm 1.7 \%$ (mean \pm SEM). In the absence of added plasma, the recovery was less than $80 \%$ and was quite variable.

A purified RBP preparation was analyzed for its possible content of free fatty acids and fatty acyl chains. Duplicate $1 \mathrm{ml}$ samples, each containing $1.1 \mathrm{mg}$ of the RBP preparation (see Results), were extracted with $\mathrm{CHCl}_{3}-\mathrm{CH}_{3} \mathrm{OH}$ containing $5 \mu \mathrm{g}$ of heptadecanoic acid (to serve as an internal standard). The lipid extract was evaporated, the residue methylated, and gas-liquid chromatography of the fatty acid methyl esters carried out, as described previously (19). Standard samples of distilled water plus 5 or $10 \mu \mathrm{g}$ of lysolecithin or free fatty acids (FFA) were carried through the same procedure at the same time. With these standard samples the added lipid was clearly and quantitatively detected.

Materials. Retinol-15- ${ }^{14} \mathrm{C}$ was the generous gift of Hoffmann-La Roche, Inc. of Basel, Switzerland. Unlabeled retinol was purchased from Eastman Kodak Chemicals, Rochester, N. Y. Antisera were obtained from Behringwerke A.G. ${ }^{5}$ The purity of the commercial antisera was not tested. Proteins of known molecular weight were obtained as a "molecular weight marker kit." 8

\footnotetext{
5 Hoechst Pharmaceutical Co., Kansas City, Mo.

${ }^{6}$ Mann Research Labs, Inc., New York.
} 


\section{RESULTS}

Lipoprotein distribution. The distribution of retinol-14 $\mathrm{C}$ among different plasma lipoproteins was determined as described above. Of the recovered retinol- ${ }^{14} \mathrm{C}, 90 \%$ was found in the protein fraction with density greater than $1.21,6 \%$ was found in the high density (d 1.063-1.21) lipoprotein fraction, and $4 \%$ in the low density (d less than 1.063) lipoprotein fraction. These findings confirm previous observations (1) that vitamin A circulates in human plasma as retinol mainly in association with proteins of density greater than 1.21.

Cohn fractionation. The results of Cohn fractionation are shown in Table I. Three-fourths of the plasma retinol, as indicated both by ${ }^{14} \mathrm{C}$ assay and by spectrophotometric assay for retinol, was recovered in Cohn Fraction I + III. All of this retinol was present in Cohn Fraction III, since removal of fibrinogen (fraction $\mathrm{I}$ ) by addition of thrombin removed none of the ${ }^{14} \mathrm{C}$, and none of the retinol, from plasma.

Column chromatography. Chromatography of Cohn Fraction I + III (derived from plasma containing retinol-14 $\mathrm{C}$ ) on a large column of Sephadex G-200 (Fig. 1) resulted in the recovery of more than $90 \%$ of the applied ${ }^{14} \mathrm{C}$ in the total eluate from the column. More than $80 \%$ of the recovered ${ }^{14} \mathrm{C}$ was eluted in a peak which appeared after the elution of the major protein peaks from the column (Fig. 1, top). The elution volume of this peak was close to that expected for serum albumin. All of the visible (green) fluorescence was eluted in the corresponding portion of the column effluent (Fig.

TABLE I

The Distribution of Retinol in Cohn Fractions of Human Plasma*

\begin{tabular}{cccc}
\hline & \multicolumn{3}{c}{ Per cent distribution of } \\
\cline { 2 - 4 } Cohn & $\begin{array}{c}\text { Total } \\
\text { protein }\end{array}$ & $\begin{array}{c}\text { Retinol- } \\
\text { 14C }\end{array}$ & $\begin{array}{c}\text { Retinol } \\
\text { (spectro- } \\
\text { photometric } \\
\text { assay) }\end{array}$ \\
\hline I + III & 22 & 73 & 76 \\
II & 10 & 3 & 6 \\
IV & 4 & 8 \\
V & 64 & 13 & 18 \\
VI & 1 & 3 & \\
\hline
\end{tabular}

* Plasma $(280 \mathrm{ml})$ was collected $66 \mathrm{hr}$ after the intravenous injection of retinol-14 $\mathrm{C}$ and was immediately fractionated by the method of Cohn et al. (16).
1 , bottom). It was estimated that gel filtration resulted in an approximately 8-fold purification of retinol-binding protein, compared to Cohn fraction I + III.

The radioactive, fluorescent fractions from the Sephadex G-200 column were pooled and the protein chromatographed on a column of DEAESephadex (see Fig. 2). In the experiment shown in Fig. 2, 98\% of the ${ }^{14} \mathrm{C}$ applied to the column was recovered in a single, sharp peak which was eluted after the peak of serum albumin and ceruloplasmin. The column fractions comprising the ${ }^{14} \mathrm{C}$ containing peak were strongly fluorescent. These fractions were combined and the protein rechromatographed on a smaller column of DEAESephadex (see Fig. 3). This resulted in the elution of a single sharp peak of fluorescence, of protein, and of radioactivity. In the experiment shown in Fig. 3, 93\% of the ${ }^{14} \mathrm{C}$ applied to the column was recovered from the column, and of this $97 \%$ was recovered in the single peak shown. The fractions comprising this peak (fractions $42-52$ in Fig. 3) were combined, dialyzed against water, and lyophilized. The resulting preparation was called the " $D$ " preparation. It was estimated that the $\mathrm{D}$ preparation contained retinol-binding protein purified approximately 600 to 700 -fold, as compared to whole plasma.

The $D$ preparation. Analysis of the $\mathrm{D}$ preparation by polyacrylamide disc gel electrophoresis (Fig. 4) revealed the presence of two major protein components: one with prealbumin mobility and one with $\alpha_{1}$ mobility. In addition, there were two minor components (one with $\alpha_{2}$ mobility, considered to be ceruloplasmin, and one with $\alpha_{1}$ mobility, migrating just anodal to the major $\alpha_{1}$ band), and three trace components. The major $\alpha_{1}$ band was strongly fluorescent; none of the other components was visibly fluorescent. This finding indicated that the protein-bound retinol of the $D$ preparation was present in association with the major $\alpha_{1}$ component.

Confirmatory evidence that retinol circulates in plasma bound to a protein of $\alpha_{1}$ mobility was obtained by paper electrophoresis and by zone electrophoresis on Pevikon. A portion of the $\mathrm{D}$ preparation from a subject injected with retinol- ${ }^{14} \mathrm{C}$ was analyzed by paper electrophoresis, together with a sample of whole plasma as a reference standard on an adjacent paper strip. After elec- 

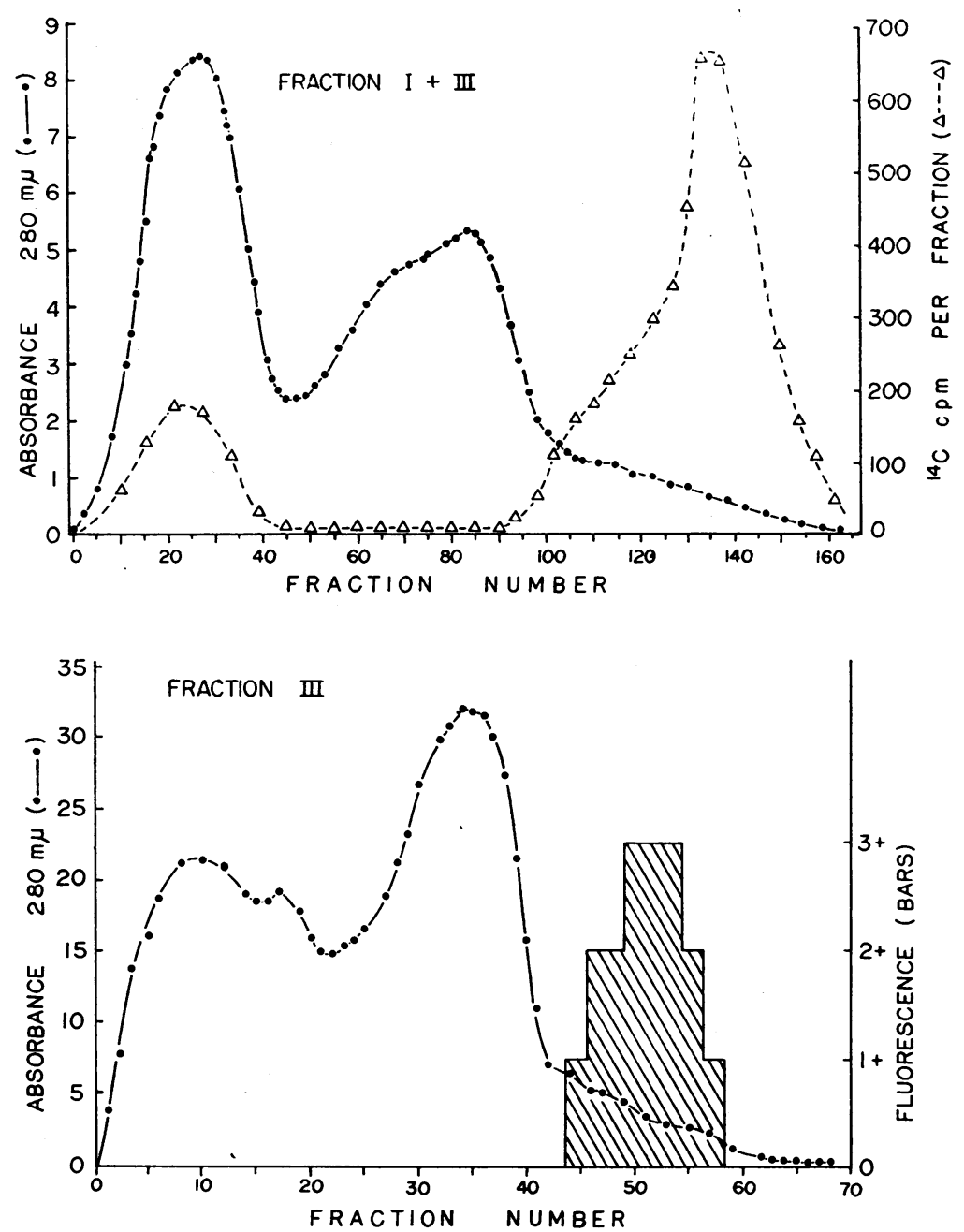

Figure 1 Gel filtration of Cohn Fraction I + III (top), or Fraction III (bottom), on columns of Sephadex G-200. The Cohn Fraction was dissolved

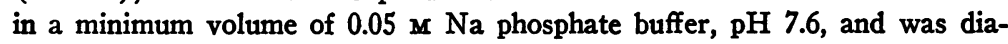
lyzed overnight against the same buffer containing $\mathrm{NaCl}, 0.2$ mole/liter. In the experiment shown in the upper panel, the sample $(87 \mathrm{ml}$ volume, derived from $280 \mathrm{ml}$ labeled plasma as shown in Table I) was applied to a column $5 \mathrm{~cm}$ internal diameter $\times 180 \mathrm{~cm}$ in length. Elution was carried out with the same phosphate buffer- $\mathrm{NaCl}$ solution at a flow rate of about 43 $\mathrm{ml} / \mathrm{hr}$. Fractions of $9 \mathrm{ml}$ each were collected. In the experiment shown in the lower panel, the sample, derived from 1.25 liters of unlabeled plasma, was applied to a column $5 \mathrm{~cm} \times 135 \mathrm{~cm}$ (bed volume 2.7 liters). The rate of elution was $27-30 \mathrm{ml} / \mathrm{hr}$, and fractions of $20-21 \mathrm{ml}$ each were collected. The fractions shown were numbered beginning with the void volume of the column. The absorbance of each fraction at $280 \mathrm{~m} \mu$ was measured, as an estimate of the protein content of the fraction; the solid curves thus show the elution of protein from the column. Small portions of the fractions were also assayed for ${ }^{16} \mathrm{C}$ (upper panel, broken curve), or were examined for fluorescence under ultraviolet light (lower panel, bars; fluorescence semiquantitatively estimated on a scale of $0-3+$ ). 


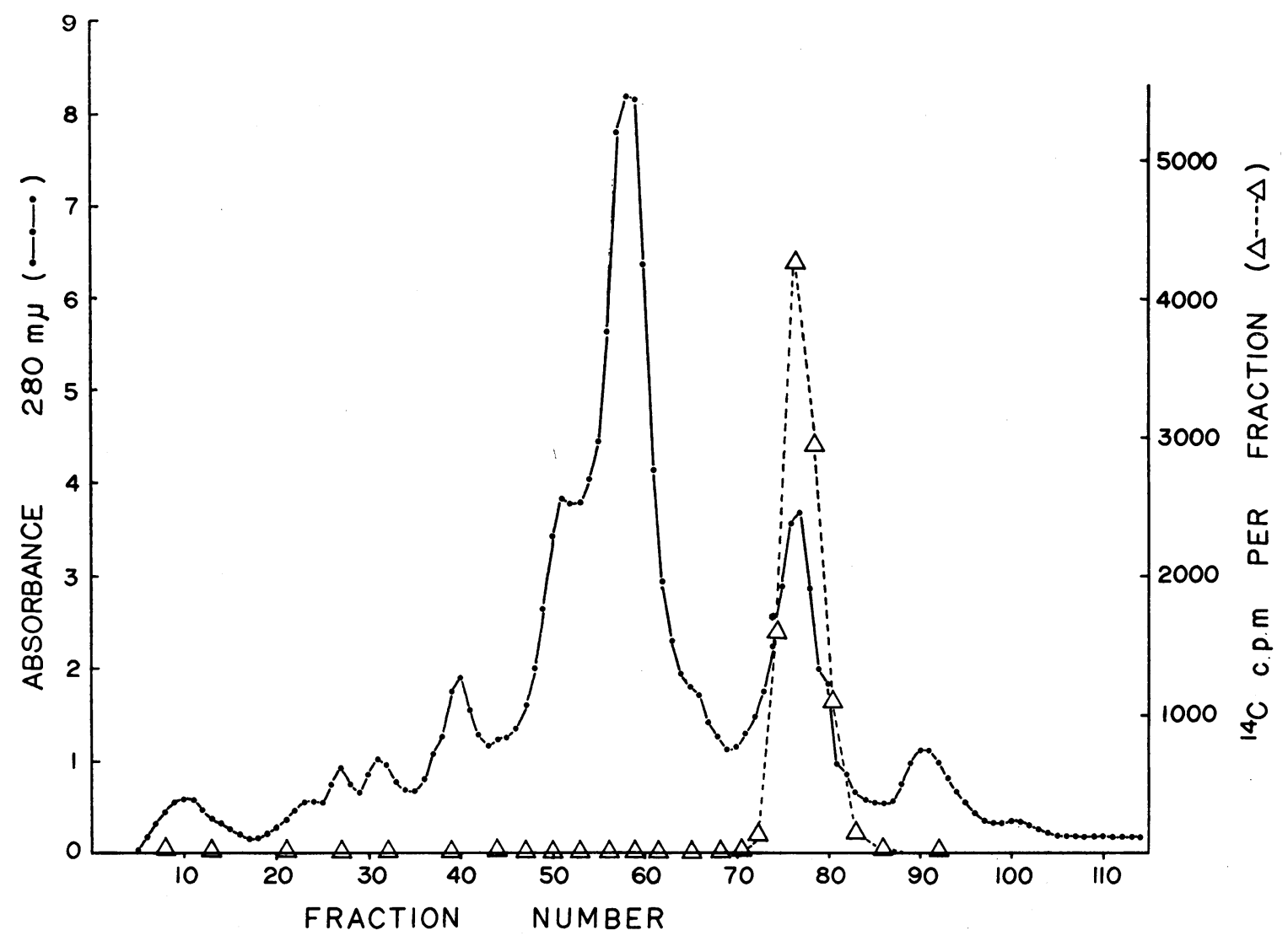

FIGURE 2 Diethylaminoethyl (DEAE)-Sephadex chromatography after Cohn fractionation and gel filtration. Plasma (1700 ml from six donors, one of whom had been injected with retinol ${ }^{14} \mathrm{C}$ ) was subjected to Cohn fractionation and gel filtration on Sephadex G-200. The radioactive, fluorescent fractions from the G-200 column were pooled and the protein precipitated with ammonium sulfate to $90 \%$ saturation. The precipitate was dissolved in

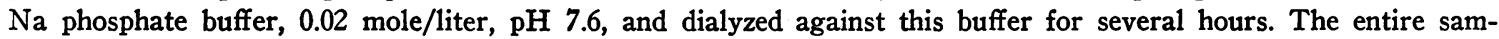
ple (volume $110 \mathrm{ml}$ ) was then applied to a column of DEAE-Sephadex, $2.7 \mathrm{~cm}$ (I.D.) $\times 58 \mathrm{~cm}$ (bed volume 330 $\mathrm{ml}$ ) packed with about $15 \mathrm{~g}$ of DEAE-Sephadex which had been extensively washed with the above phosphate buffer. Elution was carried out with $0.02 \mathrm{M} \mathrm{Na}$ phosphate buffer, $\mathrm{pH} 7.6$, with a linear gradient of $\mathrm{NaCl}$ from 0 to $0.6 \mathrm{~mole} /$ liter. Fractions of $20 \mathrm{ml}$ each were collected at a flow rate of $25-40 \mathrm{ml} / \mathrm{hr}$. The fractions were assayed for protein by absorbance at $280 \mathrm{~m} \mu$ (solid curve), and small portions were extracted and assayed for ${ }^{14} \mathrm{C}$ (broken curve). It was estimated that the radioactive peak (fractions 74-81) was eluted at a $\mathrm{NaCl}$ concentration of $0.35-0.4$ mole/liter. The relatively large protein peak in the center of the figure (fractions 55-60) consisted of serum albumin, some of which had not been removed during Cohn fractionation. Ceruloplasmin was eluted as a small shoulder (fractions 62-67) at the bottom of the descending limb of the albumin peak.

trophoresis the strips were dried in the dark under warm nitrogen. The strip containing the $\mathrm{D}$ preparation was cut lengthwise into two sections (one-fourth and three-fourths the width of the strip), and the smaller section was stained for protein. Bands of protein were seen at positions corresponding to prealbumin and to proteins of $\alpha_{1}$ mobility (as determined by reference to the strip containing whole serum); a faint protein band was also seen between the two major protein bands. The unstained section of the strip was then aligned with the stained section and was cut into four parts, corresponding respectively to prealbumin, albumin, $\alpha$-proteins, and the remainder of the strip (including the origin). The parts were extracted with warm $\mathrm{CHCl}_{3}-\mathrm{CH}_{8} \mathrm{OH}$ and the extracts assayed for ${ }^{14} \mathrm{C} .88 \%$ of the ${ }^{14} \mathrm{C}$ applied to the strip was recovered, and $68 \%$ of this was found in the $\alpha$ zone. The remaining small amount of ${ }^{14} \mathrm{C}$ was distributed throughout the rest of the 


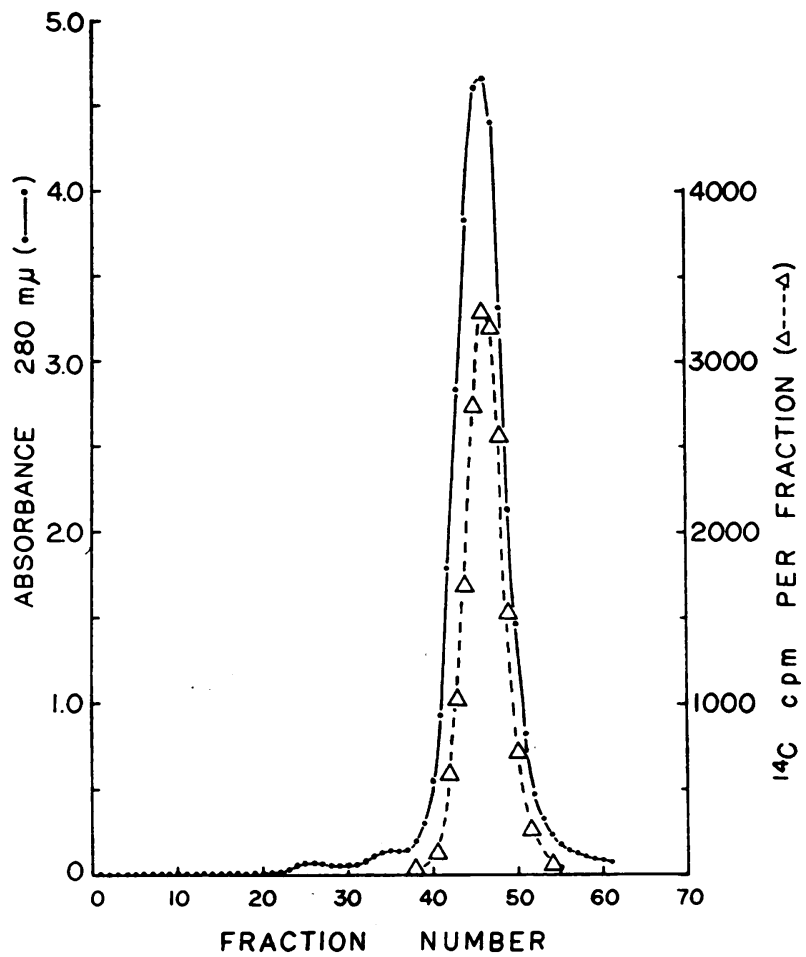

Figure 3 Repeat DEAE-Sephadex chromatography. The fractions comprising the radioactive (and fluorescent) peak from the first DEAESephadex column (Fig. 2) were pooled, dialyzed against water, and lyophilized. The dried protein was dissolved in $15 \mathrm{ml}$ of $0.02 \mathrm{M} \mathrm{Na}$ phosphate buffer, $\mathrm{pH} \mathrm{7.6,} \mathrm{and} \mathrm{applied} \mathrm{to} \mathrm{a} \mathrm{column} \mathrm{of}$ DEAE-Sephadex, $1.6 \mathrm{~cm} \times 22 \mathrm{~cm}$ (bed volume about $60 \mathrm{ml}$ ), containing about $2 \mathrm{~g}$ of DEAESephadex. Elution was carried out with the same $\mathrm{Na}$ phosphate buffer, with a convex gradient of $\mathrm{NaCl}$ from 0 to 0.44 mole/liter (using a constant volume mixing chamber of $250 \mathrm{ml}$ ). The elution rate was $20-25 \mathrm{ml} / \mathrm{hr}$, and fractions of $6.3 \mathrm{ml}$ each were collected.

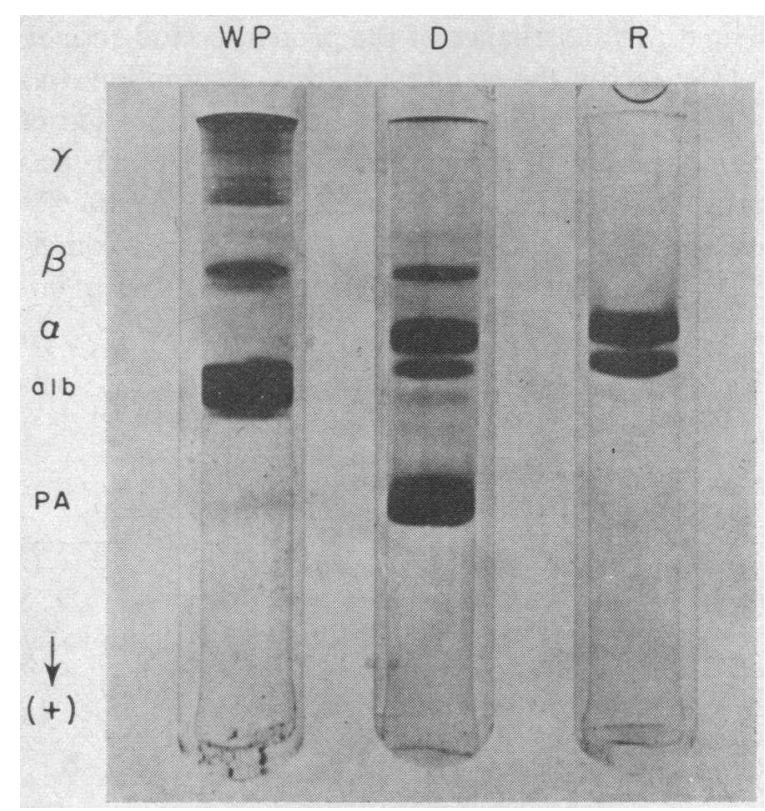

paper strip, consistent with the conclusion that it represented the occurrence of some smearing of protein during paper electrophoresis.

Zone electrophoresis was carried out with $8 \mathrm{ml}$ of whole plasma, drawn from the first subject 35 days after he had been injected with retinol- ${ }^{14} \mathrm{C}$. Fig. 5 shows the results of this experiment. 92\% of the ${ }^{14} \mathrm{C}$ applied to the Pevikon block was recovered in the albumin- $\alpha$-protein area. The position of the peak of radioactivity was slightly behind (cathodal to) the major protein peak (of serum albumin), and this position corresponded to that expected for $\alpha_{1}$-proteins in this system.

These studies therefore demonstrated that, in three different kinds of electrophoretic systems, plasma retinol was found in association with a protein of $\alpha_{1}$ mobility. This was true both for whole plasma and for the approximately 650-fold purified $\mathrm{D}$ preparation, and was indicated both by fluorescence observations and by ${ }^{14} \mathrm{C}$ assay for retinol.

Fig. 6 shows the ultraviolet absorption spectrum of the D preparation (dashed curve). The spectrum had a peak at $330 \mathrm{~m} \mu$, as well as the usual protein absorption peak near $280 \mathrm{~m} \mu$. Since retinol itself in solution in organic solvents (e.g., benzene, hexane) has its peak of absorbance at or

FIGURE 4 Polyacrylamide disc gel electrophoretic analysis of samples of (from left to right): (a) whole plasma $(W P) ;(b)$ the D preparation $(D)$; and $(c)$ the RBP preparation $(R)$. (See Results for further details.) After electrophoresis, the gels were examined under u1traviolet light and the positions of fluorescent bands precisely determined. The gel was then stained for protein. In each of the two right-hand gels shown, a strongly fluorescent band was observed before staining at exactly the position of the major $\alpha_{1}$ band. 


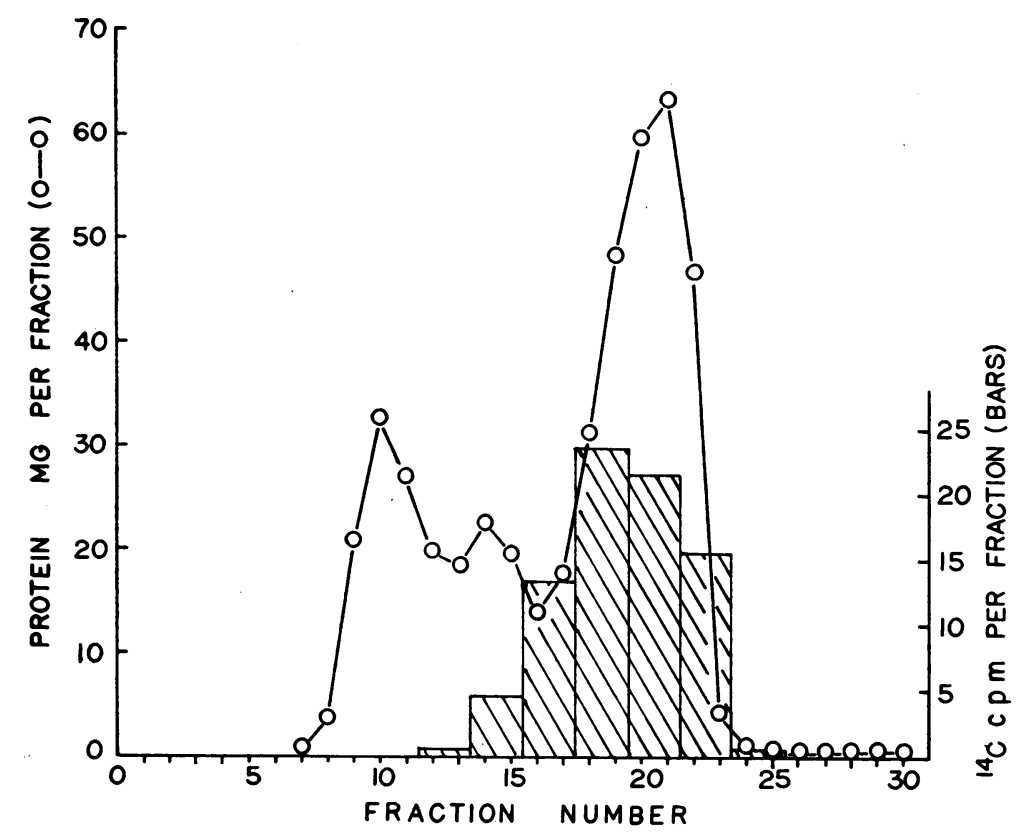

Figure 5 Zone .electrophoresis on Pevikon of whole plasma from a subject injected intravenously with retinol- ${ }^{11} \mathrm{C}$. (See Results for further details.) near $330 \mathrm{~m} \mu$, our initial assumption was that the $330 \mathrm{~m} \mu$ peak seen with the $\mathrm{D}$ preparation represented the absorbance of the protein-bound retinol. Evidence for the validity of this assumption was obtained by the finding that further purification of retinol-binding protein (see following text) was associated with an enrichment of the $330 \mathrm{~m} \mu$ absorbance (relative to $280 \mathrm{~m} \mu$ absorbance) identical with the extent of RBP purification as moni- tored by ${ }^{14} \mathrm{C}$ assay. Proof of this assumption was subsequently obtained by the development of a method for the extraction of retinol from $R B P$ into heptane without denaturation of the protein. During the course of this extraction the $330 \mathrm{~m} \mu$ absorption peak steadily diminished, whereas the $280 \mathrm{~m} \mu$ peak remained unchanged. In preliminary experiments it has also been possible to add retinol back to the extracted RBP, thus showing that the

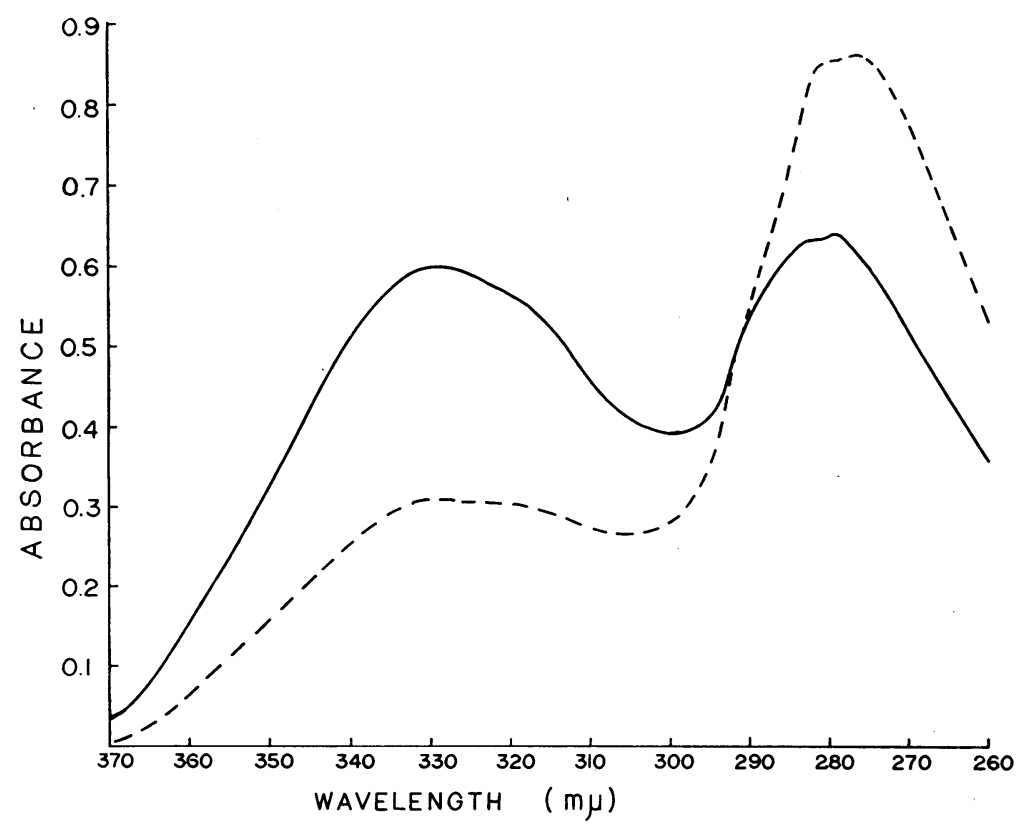

FIGURE 6 Ultraviolet absorption spectra of the $D$ preparation (dashed line) and of purified holo-RBP $\left(\mathrm{RBP}_{\mathrm{h}}\right)$ (solid line). (See Results for further details.) 
protein is capable of reassociating with added retinol. The details of these methods, together with the results of experiments carried out with these methods, will be reported in a subsequent communication.

Preparative polyacrylamide gel electrophoresis. Further purification of RBP was effected by preparative polyacrylamide gel electrophoresis (see Fig. 7). In the experiment shown in Fig. 7 the elution of protein, and of protein-bound retinol, were determined, respectively, by monitoring the eluate for ultraviolet absorption at $280 \mathrm{~m} \mu$ and at $330 \mathrm{~m} \mu$. Two major, and well-separated, peaks of protein were obtained after electrophoresis. The first peak consisted of prealbumin (as determined by disc gel electrophoresis). The second $\left(\alpha_{1}\right)$ protein peak contained $44 \%$ of the recovered protein (280 $\mathrm{m} \mu$ absorption) and $93 \%$ of the recovered retinol (330 $\mathrm{m} \mu$ absorption). All of the visible (green) fluorescence was found in the fractions comprising the second peak. In this experiment the total recovery of applied material, in the entire effluent from the gel, was $98 \%$ for protein (280 $\mathrm{m} \mu$ absorption) and $89 \%$ for retinol (330 $\mathrm{m} \mu$ absorption).

The $\mathrm{D}$ preparation derived from the experiment shown in Fig. 3 was subjected to preparative gel electrophoresis in three batches. The average recovery of applied ${ }^{14} \mathrm{C}$ in the second $\left(\alpha_{1}\right)$ peak was $77 \%$; virtually all of the ${ }^{14} \mathrm{C}$ recovered in the total effluent was found in this peak.

The fractions comprising the second electro- phoretic peak (180-290 ml effluent volume in Fig. 7) were pooled and the protein then chromatographed on a column of Sephadex G-100 (see Fig. 8). The major peak obtained after chromatography contained all of the visible fluorescence and almost all of the protein-bound retinol (as monitored by $330 \mathrm{~m} \mu$ absorbance). The fractions comprising this peak (fractions $16-19$ in Fig. 8) were pooled, and the resulting protein preparation was designated RBP.

The extent of purification of retinol-binding protein during preparative gel electrophoresis and subsequent Sephadex G-100 chromatography was estimated from the observed ratios of absorbance (330 $\mathrm{m} \mu / 280 \mathrm{~m} \mu)$ in each preparation. For the experiments shown in Figs. 7 and 8, this absorbance ratio was 0.35 for the $D$ preparation, 0.65 for the second peak (pooled fractions) after gel electrophoresis, and 0.80 for the RBP preparation. It was thus estimated that retinol-binding protein was 2.3-fold purified in the RBP preparation, as compared to the $\mathrm{D}$ preparation, and that the RBP preparation contained retinol-binding protein purified approximately 1500 -fold, compared to whole plasma. These estimates of purification are minimal estimates, since retinol is an unstable molecule, and since small amounts of protein-bound retinol are lost during the handling involved in each purification procedure.

$R B P$ : separation of two components. Analysis of the RBP preparation by disc gel electrophoresis revealed the presence of two close bands with $\alpha_{1}$

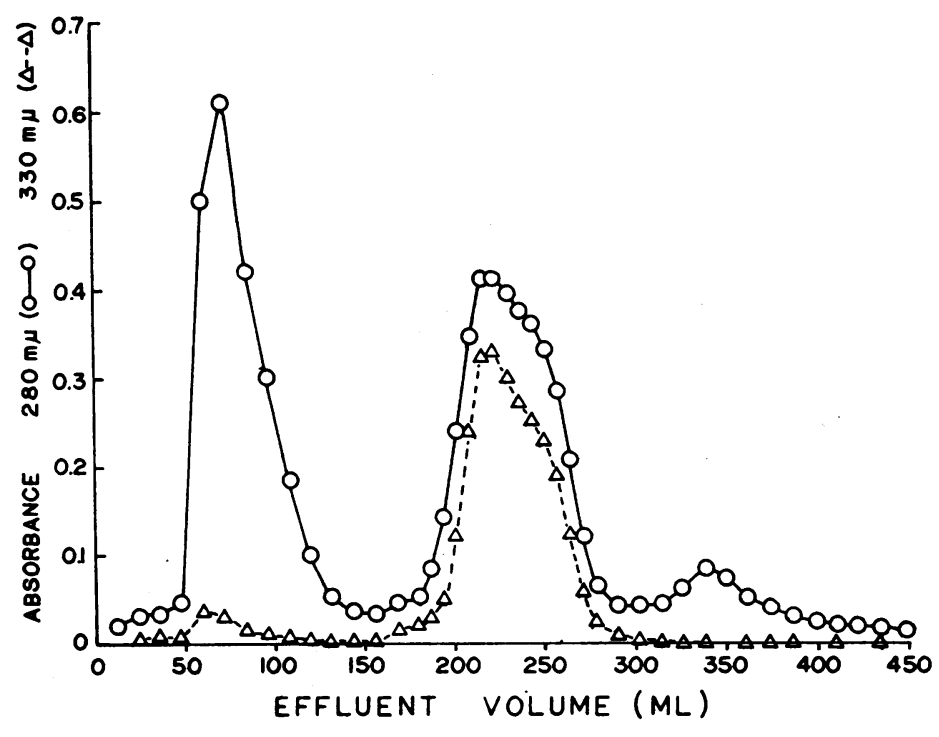

FIGURE 7 Preparative polyacrylamide gel electrophoresis of the D preparation. The gel column was $9.5 \mathrm{~cm}$ high (about $120 \mathrm{ml}$, volume). Fractions of $12 \mathrm{ml}(0-180 \mathrm{ml}$ and beyond $290 \mathrm{ml}$, effluent volume) or of $7 \mathrm{ml}$ (180-290 ml, effluent volume) were collected. 


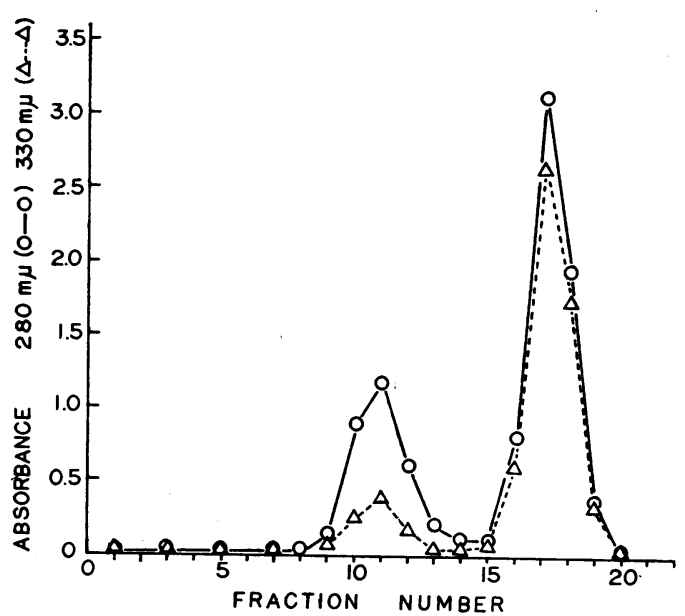

Figure 8 Sephadex G-100 chromatography after preparative gel electrophoresis. The sample from gel electrophoresis was dialyzed against water for several hours and then lyophilized. The dry sample was dissolved in 5

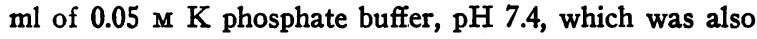
$0.2 \mathrm{M}$ in $\mathrm{NaCl}$, and applied to a column $1.6 \mathrm{~cm}$ (I.D.) $X$ $80 \mathrm{~cm}$ (bed volume $155 \mathrm{ml}$ ) in size. Elution was carried out with the same buffer solution at a rate of $11 \mathrm{ml} / \mathrm{hr}$. Fractions of $7.1 \mathrm{ml}$ were collected and assayed for absorbance at $280 \mathrm{~m} \mu$ and at $330 \mathrm{~m} \mu$. The total recovery, after chromatography, of $280 \mathrm{~m} \mu$ absorption (sum of 280 $\mathrm{m} \mu$ absorbance $\times$ volume for all fractions) was $82 \%$, and of $330 \mathrm{~m} \mu$ absorption was $76 \%$. Of the recovered ultraviolet absorbing material, the major (RBP) peak contained $64 \%$ of the recovered $280 \mathrm{~m} \mu$ absorption and $86 \%$ of the recovered $330 \mathrm{~m} \mu$ absorption.

mobility (Fig. 4, right). The more slowly migrating and major band (the upper band in Fig. 4, right) was strongly fluorescent (before staining for protein).

The RBP preparation was subjected to preparative polyacrylamide gel electrophoresis, in order to try to separate and isolate each of the two $\alpha_{1}$-protein bands. As shown in Fig. 9, this procedure substantially separated the two bands, with the smaller, more anodal band (Fig. 4) being eluted first, as a small peak, followed by a much larger, strongly fluorescent peak, corresponding to the upper band in Fig. 4. The protein-bound retinol (330 $\mathrm{m} \mu$ absorbance and fluorescence) was associated with the major peak (upper band, Fig. 4).

The pooled fractions comprising the second (major and fluorescent) peak from three runs such as that shown in Fig. 9 were combined and chromatographed on a small column of DEAESephadex. A single major peak was obtained.
The fractions comprising this peak were dialyzed against water and then lyophilized. The resulting preparation was designated $\mathrm{RBP}_{\mathbf{h}}$. The fractions comprising the first peak from the same three runs were similarly treated to produce a preparation designated $\mathrm{RBP}_{\mathrm{a}}$. The absorbance ratio $(330 \mathrm{~m} \mu$ / $280 \mathrm{~m} \mu$ ) of the $\mathrm{RBP}_{\mathrm{h}}$ preparation was 0.95 . The highest absorbance ratio observed on any of the fractions at the center of the $\mathrm{RBP}_{h}$ peak, during the three electrophoretic runs, was 1.05.

Analysis of the $\mathrm{RBP}_{\mathrm{h}}$ and $\mathrm{RBP}_{\mathrm{a}}$ preparations by disc gel electrophoresis (Fig. 10) confirmed the fact that $\mathrm{RBP}_{\mathrm{a}}$ consisted almost completely of the protein corresponding to the lower band of the RBP preparation, whereas $\mathrm{RBP}_{\mathbf{h}}$ was greatly enriched with the protein corresponding to the upper band of the RBP preparation.

The amino acid composition of each of the two $\alpha_{1}$-protein preparations $\left(\mathrm{RBP}_{\mathrm{a}}\right.$ and $\left.\mathrm{RBP}_{\mathrm{h}}\right)$ was determined. The compositions of the two preparations were virtually identical (see Table II). In addition, the two $\alpha_{1}$-proteins had identical mobilities on columns of Sephadex G-100 and of

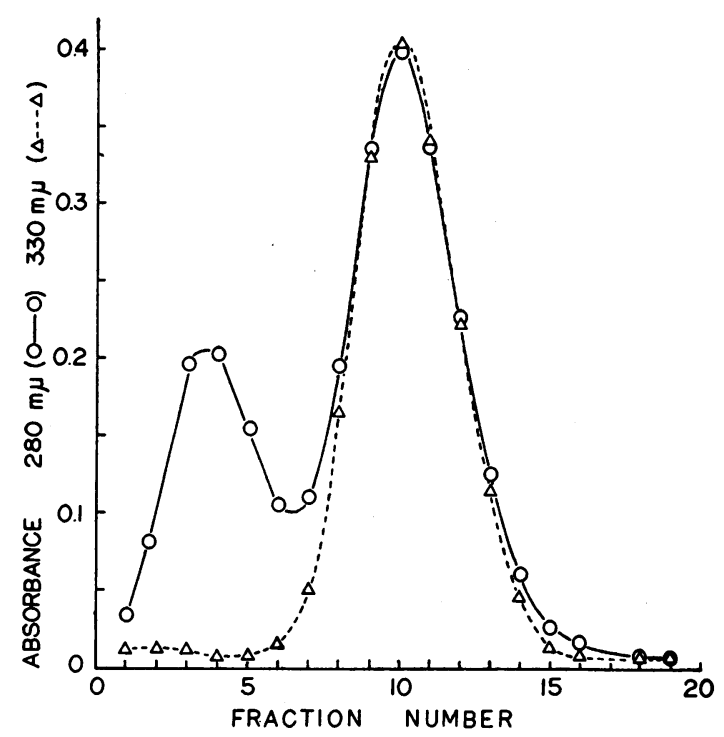

Figure 9 Preparative polyacrylamide gel electrophoresis of the RBP preparation. Approximately $9-10 \mathrm{mg}$ of the $\mathrm{RBP}$ preparation was subjected to electrophoresis in the usual way. Fractions of about $6 \mathrm{ml}$ each were collected and assayed for absorbance at $280 \mathrm{~m} \mu$ and at 330 $\mathrm{m} \mu$. The total recovery of $280 \mathrm{~m} \mu$ absorption was $86 \%$, and of $330 \mathrm{~m} \mu$ absorption was $83 \%$. In a second run, with similar separation, the recoveries of ultraviolet absorbing material were 85 and $77 \%$, for $280 \mathrm{~m} \mu$ and $330 \mathrm{~m} \mu$ absorbance, respectively. 


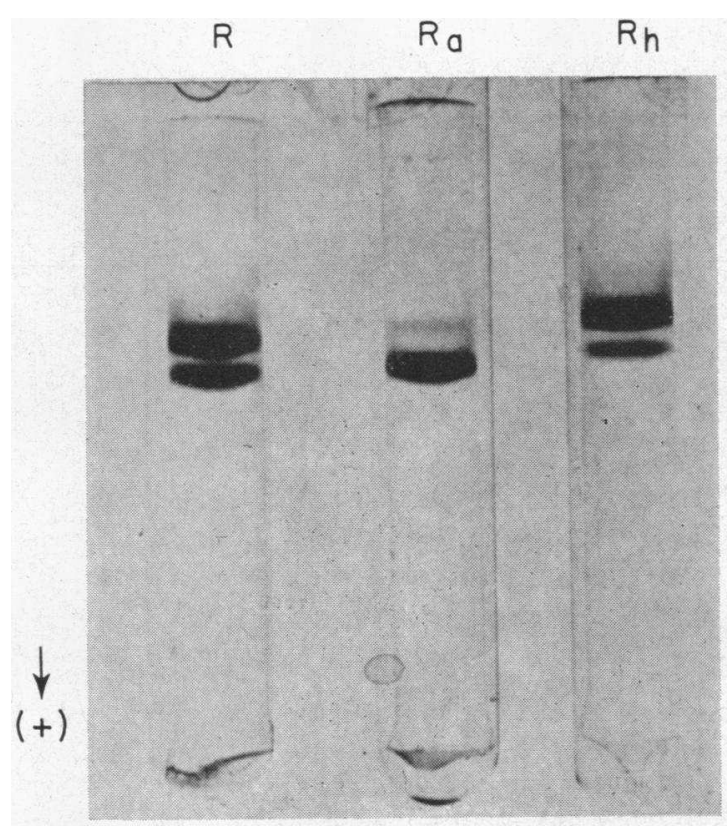

Figure 10 Polyacrylamide disc gel electrophoretic analysis of (from left to right): (a) the RBP preparation $(R)$; $(b) \operatorname{RBP}_{a}\left(R_{a}\right)$; and $(c) \operatorname{RBP}_{\mathrm{h}}\left(R_{h}\right)$. The $R B P_{a}$ and $R_{B B}$ preparations were derived from the $R B P$ preparation shown on the left.

DEAE-Sephadex. These data strongly suggested that the two $\alpha_{1}$-proteins were in fact identical, and that both represented RBP, but that the major fluorescent protein $\left(\mathrm{RBP}_{\mathrm{h}}\right)$ consisted of holo$\mathrm{RBP}$ (RBP containing bound retinol), whereas the nonfluorescent protein $\left(\mathrm{RBP}_{\mathrm{a}}\right)$ consisted of apo-RBP ( $R B P$ without bound retinol).

$R B P$ : amino acid composition. The results of amino acid analysis of $\mathrm{RBP}_{\mathrm{h}}$ are indicated in Table II. Histidine was the least abundant amino acid residue, comprising $1.05 \%$ of the total number of amino acids (on a $\mu$ molar basis). By assigning values of 1,2 , or 3 for the number of histidine residues per $\mathrm{RBP}$ molecule, it was calculated that the corresponding molecular weight of $\mathrm{RBP}$ would be in the range of about $11,000,22$,000 , or 33,000 , respectively. Since the molecular weight, as estimated by other methods (see below), appeared to be near 21,000 , this indicated that the RBP molecule must contain two histidine residues, together with the numbers of residues for each of the other amino acids as indicated in the last two columns of Table II.

The molar ratio of tyrosine to tryptophane, as determined spectrophotometrically on a portion of the $\mathrm{RBP}_{\mathrm{a}}$ preparation, was 1.95 . This indicated that $\mathrm{RBP}$ must contain four tryptophane residues per molecule, since the amino acid analysis indicated the presence of eight tyrosine residues per molecule. On a weight basis, it could then be calculated that tyrosine makes up approximately $6.1 \%$ and tryptophane approximately $3.5 \%$ of the weight of the RBP molecule. These values indicate that $\mathrm{RBP}$ contains an unusually high content of aromatic amino acids.

$R B P$ : immunodiffusion. The RBP preparation (tested as a solution of $0.34 \mathrm{mg} / \mathrm{ml}$ ) did not react with commercial antisera against whole human serum, prealbumin, albumin, $\alpha_{1}$-acid glycoprotein, or ceruloplasmin. In contrast, the $\mathrm{D}$ preparation reacted strongly with anti-prealbumin antiserum and also reacted with antisera against albumin and ceruloplasmin. Three distinct lines of immunoprecipitation were seen when the $\mathrm{D}$ preparation was tested against anti-whole human serum.

The sensitivity of the commercial antiserum against prealbumin was estimated by testing this antiserum opposite serial dilutions of purified prealbumin prepared from the $\mathrm{D}$ preparation by preparative polyacrylamide gel electrophoresis (as in Fig. 7). The antiserum reacted strongly with the purified prealbumin. A line of immunoprecipitation was obtained with a prealbumin concentration of $0.0064 \mathrm{mg} / \mathrm{ml}$, but not with a prealbumin concentration of half this much. Since the RBP solution of $0.34 \mathrm{mg} / \mathrm{ml}$ did not react with anti-prealbumin antiserum, this indicated that the RBP preparation could not contain as much as $1.9 \%$ (by weight) of prealbumin.

RBP: molecular weight and sedimentation velocity. Sedimentation velocity studies demonstrated that $\mathrm{RBP}_{\mathrm{h}}$ migrated as a single, homogeneous component, with a sedimentation constant $\left(s_{20, w}\right)$ of $2.26 \mathrm{~S}$ (for a $1 \mathrm{mg} / \mathrm{ml}$ solution). The molecular weight was estimated, by sedimentation equilibrium analysis, to be $20,800 \pm 2000$ (mean $\pm \mathrm{SD}$ ). The molecular weight of RBP was also estimated by chromatography of a portion of the RBP preparation on a standardized column of Sephadex G-100 (Fig. 11, solid line): This study indicated that the molecular weight of RBP was approximately 20,400 (assuming ideal behavior in this chromatographic system). Finally, from the amino acid composition shown in the last

Vitamin A Transport in Human Plasma 
TABLE II

The Amino Acid Compositon of RBP*

\begin{tabular}{|c|c|c|c|c|c|c|c|c|}
\hline \multirow{3}{*}{ Amino acid } & \multicolumn{2}{|c|}{$\begin{array}{l}\% \text { distribution of } \\
\text { observed } \mu \text { moles }\end{array}$} & \multirow{2}{*}{\multicolumn{3}{|c|}{ Observed $\mu$ moles $\times 10^{2}$}} & \multirow{3}{*}{$\begin{array}{c}\text { Corrected } \\
\% \text { distribu- } \\
\text { tion of } \\
\mu \text { moles } \ddagger\end{array}$} & \multirow{3}{*}{$\begin{array}{c}\mu \text { moles of each } \\
\text { amino acid, } \\
\text { relative to } \\
\text { histidine } \delta\end{array}$} & \multirow{3}{*}{$\begin{array}{c}\text { Estimated No. } \\
\text { of residues } \\
\text { per RBP } \\
\text { molecule }\end{array}$} \\
\hline & \multirow[t]{2}{*}{$\mathrm{RBP}_{\mathbf{s}}$} & \multirow[t]{2}{*}{$\mathrm{RBP}_{\mathrm{h}}$} & & & & & & \\
\hline & & & $24 \mathrm{hr}$ & $48 \mathrm{hr}$ & $72 \mathrm{hr}$ & & & \\
\hline Lysine & 5.73 & 5.75 & 8.95 & 9.17 & 9.08 & 5.51 & 10.50 & $10-11$ \\
\hline Histidine & 1.06 & 1.10 & 1.70 & 1.75 & 1.74 & 1.05 & 2.00 & 2 \\
\hline Arginine & 8.01 & 8.04 & 12.70 & 12.40 & 12.40 & 7.59 & 14.46 & $14-15$ \\
\hline Aspartic acid & 15.80 & 15.70 & 25.10 & 25.10 & 25.60 & 15.35 & 29.24 & 29 \\
\hline Threonine & 5.07 & 5.07 & 8.04 & 7.79 & 7.89 & 5.01 & 9.54 & $9-10$ \\
\hline Serine & 6.17 & 5.88 & 9.36 & 9.09 & 8.91 & 5.93 & 11.30 & 11 \\
\hline Glutamic acid & 10.70 & 10.60 & 17.90 & 18.20 & 18.10 & 10.97 & 20.90 & 21 \\
\hline Proline & 3.21 & 3.05 & 4.73 & 4.77 & 5.12 & 2.96 & 5.64 & $5-6$ \\
\hline Glycine & 6.53 & 6.41 & 10.30 & 10.50 & 11.10 & 6.46 & 12.30 & 12 \\
\hline Alanine & 7.65 & 7.63 & 12.30 & 12.60 & 12.60 & 7.59 & 14.46 & $14-15$ \\
\hline Half-cystine & 2.67 & 2.63 & 4.47 & 5.16 & 4.76 & 2.92 & 5.56 & $5-6$ \\
\hline Valine & 6.41 & 6.20 & 11.10 & 11.70 & 12.40 & 7.45 & 14.19 & 14 \\
\hline Methionine & 1.85 & 2.08 & 2.96 & 2.91 & 3.09 & 1.81 & 3.45 & $3-4$ \\
\hline Isoleucine & 1.40 & 1.36 & 2.80 & 3.30 & 3.60 & 2.17 & 4.13 & 4 \\
\hline Leucine & 7.79 & 7.85 & 12.40 & 12.10 & 12.40 & 7.47 & 14.23 & 14 \\
\hline Tyrosine & 4.16 & 4.50 & 7.22 & 6.79 & 6.86 & 4.22 & 8.04 & 8 \\
\hline \multirow[t]{2}{*}{ Phenylalanine } & 5.78 & 6.13 & 9.39 & 8.96 & 9.04 & 5.55 & 10.57 & $10-11$ \\
\hline & 100.00 & 100.00 & 161.40 & 162.30 & 164.70 & 100.00 & 190.50 & $185-193$ \\
\hline
\end{tabular}

* Two studies were carried out at an interval of 5 months. In the first study (first 2 columns of numbers) samples of $\mathrm{RBP}_{\mathrm{a}}$ and $\mathrm{RBP}_{\mathrm{h}}$ were hydrolyzed at the same time, for $22 \mathrm{hr}$, for the purpose of comparing the amino acid composition of the two preparations. In the second study (remainder of columns), portions of $\mathrm{RBP}_{\mathrm{h}}$ were hydrolyzed for 24,48 , or $72 \mathrm{hr}$, in order to more fully define the amino acid composition of RBP.

$\ddagger$ The corrected percentage distribution lists the average of the three values observed for each amino acid (for 24,48 , and $72 \mathrm{hr}$ hydrolysis) except for: (a) threonine and serine, in which the observed values were extrapolated back to zero time, and this value was used; $(b)$ valine and isoleucine, in which the 72-yr values were used. The final values were adjusted so that their sum equals $100 \%$.

$\S$ Relative to histidine which was assigned the value of 2.00 (see Results).

column of Table II (and including the four tryptophane residues estimated to be present per molecule) it was calculated that the molecular weight should be in the range of $21,600-22,600$. Since the results of the different methods for estimating the molecular weight of $\mathrm{RBP}$ agreed quite well, it seems fairly secure that $\mathrm{RBP}$ has a molecular weight of approximately 21,000-22,000.

$R B P$ : spectral studies; retinol content. The absorption spectrum of the $\mathrm{RBP}_{\mathbf{h}}$ preparation is shown in Fig. 6, solid curve. The spectrum had two peaks, of nearly equal height.

The retinol content of the RBP preparation was determined by extraction and chromatography of $1 \mathrm{ml}$ of a solution of RBP with a peak absorbance at $330 \mathrm{~m} \mu$ of 0.415 . The benzene solution of the extracted retinol was adjusted to the same volume as that of the RBP solution which had been ex- tracted $(1 \mathrm{ml})$. This benzene solution had a typical retinol absorption peak at $330 \mathrm{~m} \mu$, with an absorbance at $330 \mathrm{~m} \mu$ of 0.372 (corrected for control values as indicated under Methods). When corrected for the $89.9 \%$ recovery of retinol obtained with standard samples in this procedure, the absorbance of the benzene solution of retinol was calculated to be 0.414 at $330 \mathrm{~m} \mu$. The absorbance at $330 \mathrm{~m} \mu$ of the retinol extracted from RBP and in solution in benzene was thus identical with the absorbance of the aqueous solution of RBP from which it had been derived. Since retinol is known to be quantitatively extracted from plasma by the method used, this indicates that, at the absorption peak of approximately $330 \mathrm{~m} \mu$, the molar extinction of retinol bound to RBP (in aqueous solution) is identical with that of retinol in solution in benzene. 


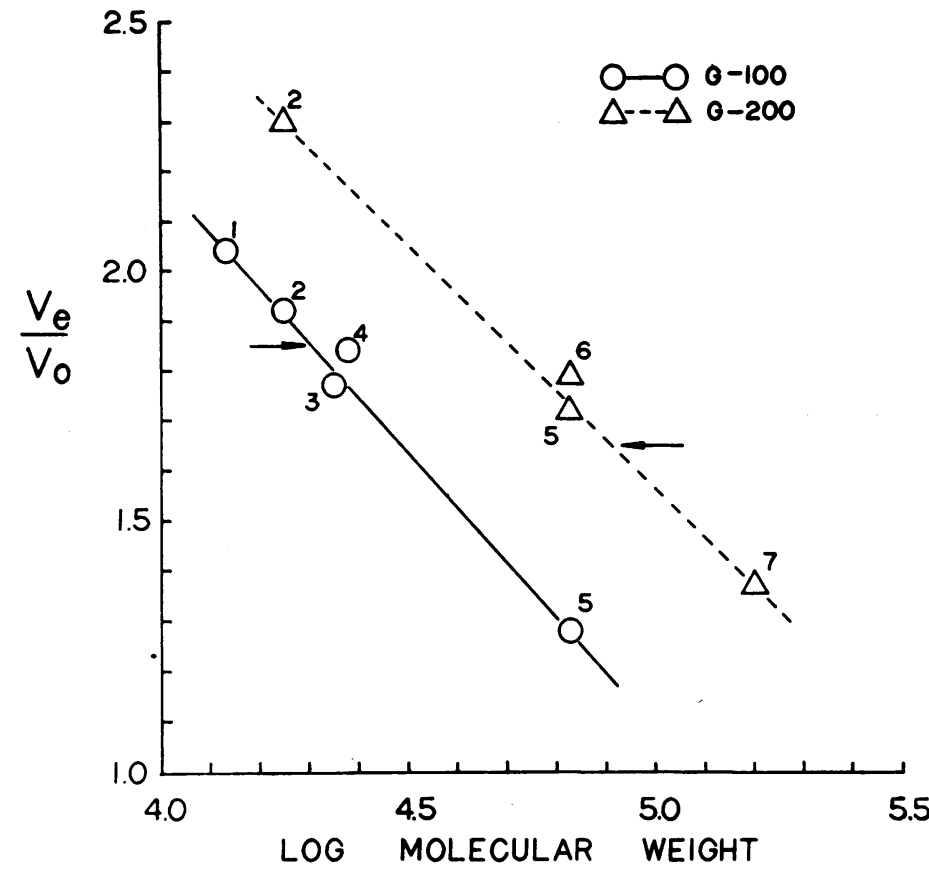

FIGURE 11 Estimation of molecular weight by gel filtration. A portion of the RBP preparation was dissolved in $0.05 \mathrm{M} \mathrm{K}$ phosphate buffer, $\mathrm{pH} 7.5$, also $0.2 \mathrm{M}$ in $\mathrm{NaCl}$, and chromatographed on a column of Sephadex G-100, $1.6 \mathrm{~cm}$ (I.D.) $\times 90 \mathrm{~cm}$ in size. Elution was carried out with the same buffer at a flow rate of $12 \mathrm{ml} / \mathrm{hr}$. The absorbance of the effluent stream at $280 \mathrm{~m} \mu$ was monitored continuously. A portion of the D preparation was similarly chromatographed on a column of Sephadex G-200. The columns were standardized by chromatography on them of small samples (2-4 mg) of proteins of known molecular weight. A small amount of blue dextran polymer (mol wt $2 \times 10^{\circ}$ ) was added to each sample before chromatography, in order to determine the void volume $\left(V_{0}\right)$. After chromatography, the effluent volume (V.) corresponding to the center of the peak of eluted protein was measured, and the values of $V_{\bullet} / V_{0}$ were then plotted against the log of the molecular weight. The observed values of $V_{0} / V_{0}$ for the RBP and the $\mathrm{D}$ preparations are indicated above by the left-hand and the right-hand arrows, respectively; the molecular weights of these preparations were then estimated as shown (20). The standard proteins were: No. 1 , ribonuclease; No. 2, myoglobin; No. 3, chymotrypsin; No. 4, trypsin; No. 5, human serum albumin; No. 6, bovine serum albumin; No. 7, gamma globulin.

The $E_{1 \mathrm{~cm}}^{1 \%}$ at $280 \mathrm{~m} \mu$ was determined by measuring the protein content (18) of solutions of RBP which had been assayed in the spectrophotometer. In two determinations, the identical value of 16.5 was obtained. This value is unusually high and is consistent with the very high content of tyrosine and tryptophane found in RBP. Furthermore, it is almost certain that the true value for the $E_{1 \mathrm{~cm}}^{1 \%}$ at $280 \mathrm{~m} \mu$ is higher than this, since it is known that the extinction coefficient of the
Lowry color reaction is increased by aromatic amino acids $(18,21)$. The protein content would therefore have been overestimated by the method as used, i.e., when standardized against bovine serum albumin. In studies with thyroxine-binding prealbumin, a protein fairly rich in aromatic amino acids, Oppenheimer, Surks, Smith, and Squef determined that the protein level measured by the Lowry color reaction (standardized against bovine serum albumin) should be multiplied by 0.89 
in order to obtain the true protein concentration (21). Since RBP has an even higher content of aromatic amino acids than does prealbumin, we estimated that the measured protein levels should have been multiplied by a factor of 0.85 in order to obtain the correct protein concentration. The corrected $E_{1 \mathrm{~cm}}^{1 \%}$ at $280 \mathrm{~m} \mu$ was thus estimated to be approximately 19.4 .

Finally, from the values of the molar extinction coefficient of retinol attached to RBP (the same as that of retinol in benzene), and the $E_{1 \mathrm{~cm}}^{1 \%}$ for RBP (19.4), the weight of protein associated with $1 \mu$ mole of retinol in RBP could be calculated. In making this calculation we assumed that the absorbance ratio $(330 \mathrm{~m} \mu / 280 \mathrm{~m} \mu)$ for holo-RBP was 1.05 (the highest ratio observed in any of the electrophoretic fractions during preparation of $\left.\mathrm{RBP}_{\mathbf{h}}\right)$. This calculation indicated that in holo$\mathrm{RBP} 1 \mu$ mole of retinol is associated with approximately $22,600 \mathrm{mg}$ of protein, i.e., with approximately $1.0 \mu$ mole of RBP. This finding suggests that the RBP molecule contains one binding site for retinol, occupied by a single retinol molecule in holo-RBP. It is, of course, also possible that $\mathrm{RBP}$ contains binding sites for more than one molecule of retinol, but that these sites were not saturated in our purified preparation.

$R B P$ : lipid analysis. Analysis of the RBP preparation for fatty acid and fatty acyl chains indicated that no fatty acid chains (or FFA) were present, at a level of sensitivity of the method used which would have detected easily as little as one fatty acyl chain per molecule of RBP. Analyses for other lipid moieties (e.g., cholesterol) have not as yet been carried out.

$R B P$ : size reduction during purification. It was noted during the course of the purification sequence described above that the molecular size of the retinol-containing protein apparently decreased during polyacrylamide gel electrophoresis. This finding is illustrated by the experiment described in Fig. 12. In this experiment, portions of the D preparation, and of the prealbumin and RBP-containing peaks obtained after gel electrophoresis of the $\mathrm{D}$ preparation (as in Fig. 7), were serially chromatographed under identical conditions on the same column of Sephadex G-100. Before gel electrophoresis, the protein and the protein-bound retinol (fluorescence and $330 \mathrm{~m} \mu$ absorption) of the $\mathrm{D}$ preparation were eluted together in a single major peak of effluent volume of $48 \mathrm{ml}$. The position of this peak was very close to that of human serum albumin (effluent volume of $51 \mathrm{ml}$ ). After gel electrophoresis prealbumin was eluted at a similar effluent volume $(51 \mathrm{ml})$. The RBP obtained after gel electrophoresis was, however, eluted much later, at an effluent volume of $72 \mathrm{ml}$, suggesting that it had decreased considerably in size during the procedure of gel electrophoresis.

In order to quantitate the change in size occurring during gel electrophoresis, a portion of the $\mathrm{D}$ preparation was chromatographed on a standardized column of Sephadex G-200 (see Fig. 11). The protein and the protein-bound retinol were eluted together at an effluent volume corresponding to a molecular weight of about 83,000 . In contrast, as already mentioned the RBP preparation was eluted from Sephadex columns at effluent volumes corresponding to 20,000-21,000. These estimates of size assume, of course, ideal behavior during gel filtration and might be incorrect if major conformational changes occurred during the preparation of $\mathrm{RBP}$ from the $\mathrm{D}$ preparation.

RBP: interaction with prealbumin. These findings suggested that RBP normally circulates in plasma in the form of a complex which dissociates into subunits during gel electrophoresis. Experiments were therefore undertaken to define the nature of the complex present in the $\mathrm{D}$ preparation. In the initial experiments, preparative polyacrylamide gel electrophoresis was carried out under a variety of different conditions, in the hopes of obtaining a protein complex with $\alpha_{1}$ mobility, consisting of more than one RBP subunit. These experiments were completely unsuccessful; under all conditions tested RBP preparations with similar properties were obtained.

The nature of the complex present in the $D$ preparation was finally defined by the experiment illustrated in Fig. 13. Purified prealbumin and $\mathrm{RBP}$, both obtained by gel electrophoresis of the $\mathrm{D}$ preparation, were mixed together to form three different solutions, with different ratios of prealbumin to RBP. ${ }^{7}$ The three solutions were then serially chromatographed on the same column of Sephadex G-100. As shown in the top panel of

\footnotetext{
7 Separate studies of the interaction of prealbumin with $\mathrm{RBP}_{\mathrm{h}}$ and $\mathrm{RBP}_{\mathrm{a}}$ were not carried out because of the limited amount of protein available in these preparations.
} 
Fig. 13, when the ratio of prealbumin to RBP was slightly higher than that present in the $\mathrm{D}$ preparation, the two proteins chromatographed together on the Sephadex column and were eluted at an effluent volume of about $96 \mathrm{ml}$, corresponding to a molecular weight in the range of 85,000 (similar to that seen with the $\mathrm{D}$ preparation). In contrast, if RBP had been chromatographed alone on this column it would have been eluted much later, at an effluent volume of about $140 \mathrm{ml}$ (corresponding to its molecular weight of about 21,000 ). This experiment therefore demonstrated the formation of a complex between prealbumin and RBP.
The capacity of prealbumin for complex formation with RBP seems to be quite limited. Thus, when the relative amount of $R B P$ in the mixture was increased progressively (middle and bottom panels of Fig. 13), the prealbumin apparently became saturated with RBP, and the excess, uncomplexed RBP was then eluted at an effluent volume characteristic of purified RBP alone. Since the ratio of prealbumin to $R B P$ in the $D$ preparation lies between the ratios of the solutions shown in the top and middle panels of Fig. 13, it would appear that the prealbumin of the $\mathrm{D}$ preparation is saturated with respect to RBP. Furthermore,

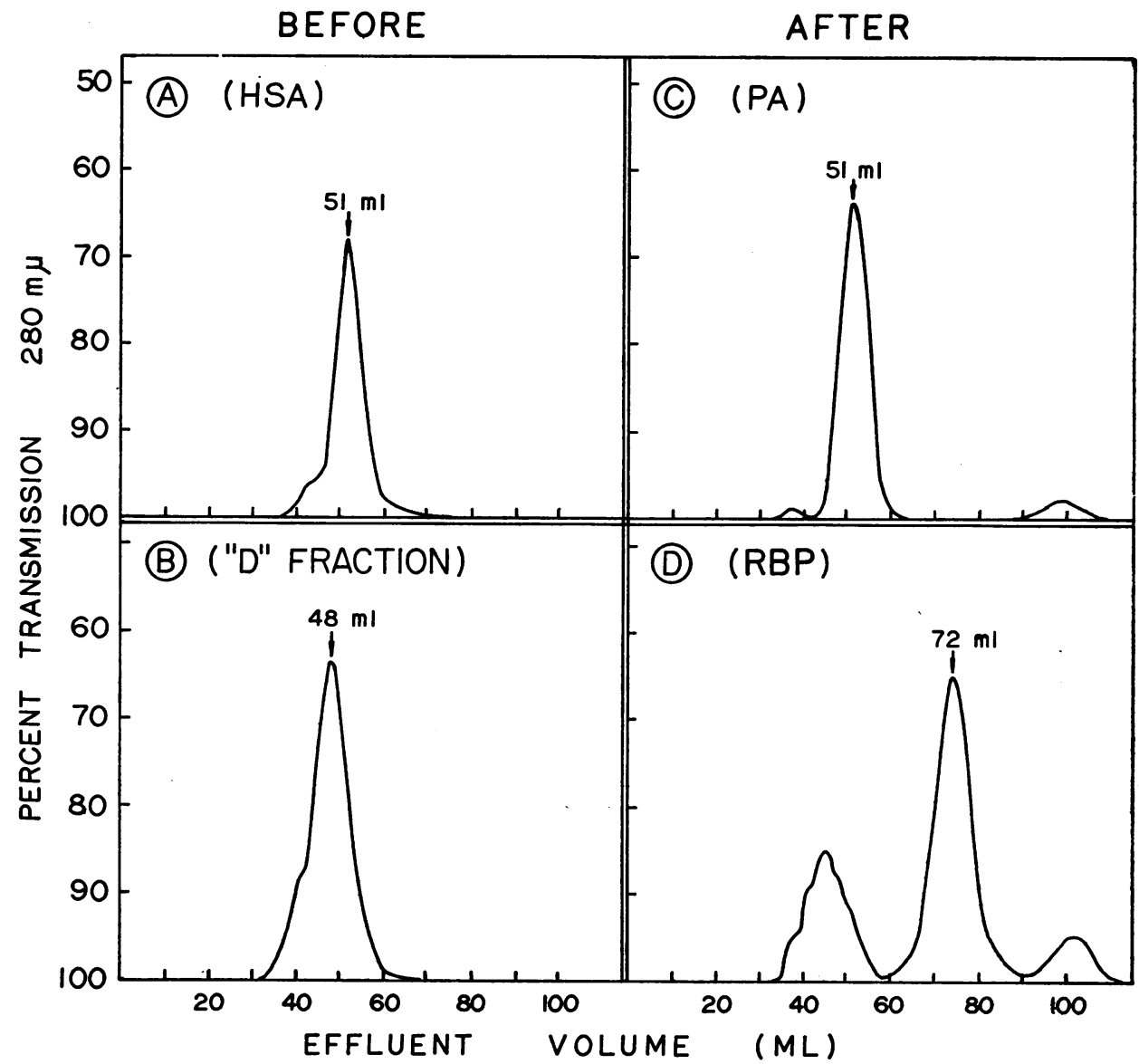

FIGURE 12 Gel filtration before and after preparative polyacrylamide gel electrophoresis. A single column of Sephadex G-100, $1.6 \mathrm{~cm} \times 52 \mathrm{~cm}$ (bed volume $100 \mathrm{ml}$ ) in size, was used for the four chromatographic analyses shown. Samples of 5-10 mg of protein were each dissolved

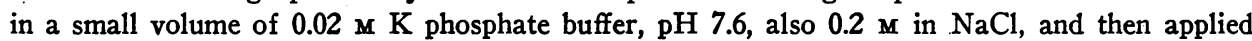
to the column. Elution was carried out with the same buffer at a rate of $7-8 \mathrm{ml} / \mathrm{hr}$. Fractions of $3.8 \mathrm{ml}$ were collected. The effluent stream was continuously monitored for absorption of light of wavelength $280 \mathrm{~m} \mu$. Panel $\mathrm{A}$, human serum albumin $(H S A)$; panel $\mathrm{B}$, the $\mathrm{D}$ preparation; panel $\mathrm{C}$, the prealbumin peak $(P A)$ obtained after electrophoresis; panel $\mathrm{D}$, the RBP peak obtained after gel electrophoresis. The major peaks in panel B (at $48 \mathrm{ml}$ ) and in panel D (at 72 $\mathrm{ml}$ ) were strongly fluorescent. 


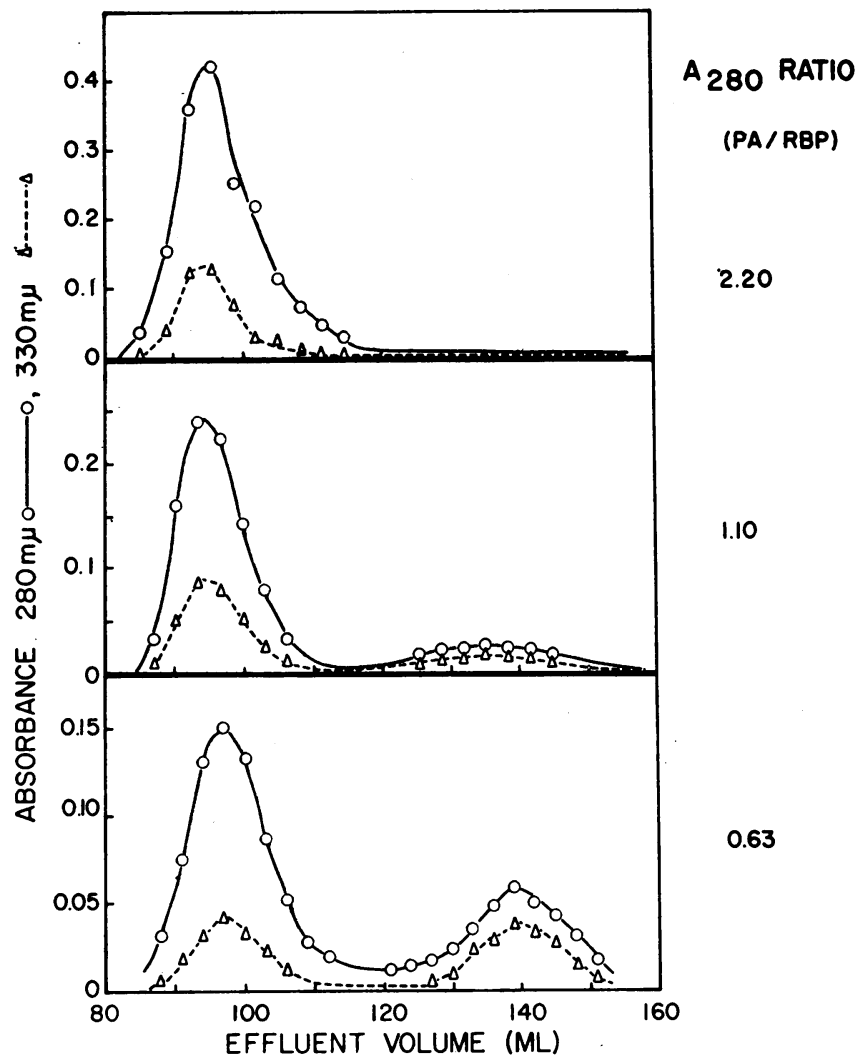

FIGURE 13 Gel filtration of prealbuminRBP mixtures. Three mixtures of identical volumes but with different ratios of prealbumin to RBP were chromatographed serially on a single column of Sephadex G-100. The relative amounts of the two proteins were estimated from the ratio of the absorbance at $280 \mathrm{~m} \mu$ due to prealbumin compared with that due to RBP, in the final mixture (as indicated on the right). The conditions of chromatography were similar to those indicated in the legend to Fig. 11. (See Results for further details.)

since the concentration (in milligrams per milliliter) of the prealbumin-RBP complex seen in the fractions eluted from the Sephadex column (Fig. 13) was only slightly greater than the estimated levels of these proteins in whole plasma, it seems likely that RBP normally circulates in plasma in the form of a complex with prealbumin.

As a control to the experiment shown in Fig. 13 , human serum albumin and RBP were mixed together in a ratio of approximately twice that of the prealbumin-RBP mixture shown in the top panel of Fig. 13. Chromatography of this mixture on a column of Sephadex G-100 resulted in the elution of two completely separated peaks, the first consisting solely of serum albumin and the second of RBP. Hence, no complex formation occurred between serum albumin and RBP. In a later experiment, a similar mixture of purified $\alpha_{1}$ acid glycoprotein $(22)^{8}$ and RBP was chromatographed on Sephadex G-100; as with serum al-

8 This plasma protein migrates slightly in front of serum albumin (between albumin and prealbumin) on disc gel electrophoresis and was purified in our laboratory by column chromatography and electrophoresis. bumin, absolutely no complex formation was discerned between the two proteins. These experiments suggest that the formation of a complex between prealbumin and RBP is highly specific for these two particular proteins.

\section{DISCUSSION}

The experiments reported here demonstrate that retinol circulates in plasma bound to a specific plasma protein, retinol-binding protein. This protein has $\alpha_{1}$ mobility, a molecular weight of approximately $21,000-22,000$, and differs from all previously identified plasma proteins. $\mathrm{RBP}$ has a sedimentation constant $\left(s_{20, v 0}\right)$ of $2.26 \mathrm{~S}$, a hydrated density greater than 1.21 , and contains no free fatty acid or fatty acyl chains. As isolated, purified holo-RBP contained approximately one retinol molecule per molecule of RBP, a finding which suggests that RBP possesses a single binding site for one molecule of retinol. From the levels of retinol normally circulating in human plasma, we can estimate that the usual level of RBP in plasma is of the order of $3-4 \mathrm{mg} / 100 \mathrm{ml}$. This estimate indicates that our final RBP preparation 
must have been purified about 1500 to 2000 -fold, and confirms our estimate of purification as derived from the recovery of protein and proteinbound retinol during each of the purification procedures.

Retinol is a 20-carbon alcohol which resembles cholesterol in many of its physicochemical properties. Cholesterol and other lipids (except for FFA [23] and lysolecithin [24]) circulate in plasma mainly as part of plasma lipoprotein molecules with hydrated densities of less than 1.21 (25). Small amounts of plasma cholesterol (and other lipids) are also found in association with very high density lipoproteins, of density greater than 1.21 (26). On a priori grounds, one might expect the lipid alcohol retinol also to circulate in plasma in association with one or more of the known plasma lipoproteins. The fact that retinol circulates instead bound to a different protein, $R B P$, indicates that the interaction between retinol and RBP must be highly specific. Further characterization of this specific interaction may provide some useful information about lipid-protein interactions in general. By definition, holo-RBP is a lipoprotein, since it consists of a complex between a lipid alcohol (retinol) and a protein (RBP).

Some information is available about the interaction between retinol and RBP. In the first place, it is clear that no covalent linkages are involved in this interaction, since retinol can readily be extracted from RBP by organic solvents. Furthermore, it seems likely that the molecular configuration of retinol is not markedly different when it is bound to RBP, or when it is in solution in organic solvents. This conclusion derives from the spectral observations that: $(a)$ the position of the absorption peak of retinol bound to RBP and in aqueous solution $(330 \mathrm{~m} \mu)$ was the same (or nearly the same) as that of retinol in solution in organic solvents; and $(b)$ the molar extinction at $330 \mathrm{~m} \mu$ of retinol bound to RBP (in aqueous solution) was identical with that of free retinol in solution in benzene. In contrast, a fine dispersion of retinol alone in water displays a broad band of ultraviolet absorption below $320 \mathrm{~m} \mu$ with a lower molar extinction.

RBP isolated from plasma consisted of a mixture of two components, both with $\alpha_{1}$ mobility, but which separated from each other on polyacrylamide gel electrophoresis. The two components had the same amino acid composition, the same molecular size, and identical chromatographic properties. Since the major of these two components contained bound retinol, whereas the other component did not, we tentatively identified these components as representing, respectively, holo$\mathrm{RBP}$ and apo-RBP. The ratio of holo-RBP to apo-RBP in purified RBP preparations was usually about 4 to 1 . Since small amounts of proteinbound retinol were lost during the purification procedures, it is likely that much of the apo-RBP found in the purified product arose during the course of the purification. It is, however, also possible that a small amount of apo-RBP is normally present circulating in plasma. Further work will be required in order to answer this question.

The amino acid composition of RBP differs from that of any previously reported plasma protein, including the protein moieties of both the high density, $\alpha$-lipoprotein, and the low density, $\beta$-lipoprotein (27-33). The ratio of polar to nonpolar amino acids in RBP is not particularly unusual for a globular protein. RBP is unusual, however, in containing a very high content of aromatic amino acids, with estimated tyrosine and tryptophane contents of 8 residues/molecule $(6.1 \%$ by weight), and 4 residues/molecule $(3.5 \%$ by weight), respectively. The high tryptophane and tyrosine content of RBP is responsible for the estimated very high value of the extinction coeffcient at $280 \mathrm{~m} \mu\left(E_{1 \mathrm{~cm}}^{1 \%}=19.4\right)$. The tryptophane content and extinction coefficient of RBP are even higher than the corresponding values for the so-called "tryptophane-rich" prealbumin of plasma, which has been reported to have a tryptophane content of $2.5 \%$ (34) or $3.15 \%$ (21), and an $E_{1 \mathrm{~cm}}^{1 \%}$ at $280 \mathrm{~m} \mu$ of 14.4 (34) or 13.6 (21). RBP also contains $10-11$ residues of phenylalanine per molecule.

Some inferences can be drawn about the possible structure of the binding site for retinol in RBP. First of all, the retinol molecule contains five conjugated double bonds, which together impart some aromatic character to the molecule. In addition, from crystallographic studies retinol is known to be a relatively flat, planar molecule, in which the trans, conjugated double bonds, and the $\beta$-ionone ring tend to lie within a single plane. Secondly, recent $x$-ray crystallographic studies of the structure of proteins have shown the presence

Vitamin A Transport in Human Plasma 2041 
of clefts in the three-dimensional structure of proteins, at their functional centers. Thus, myoglobin contains a cleft in its three-dimensional structure, and the heme prosthetic group resides within this cleft (35). Lysozyme also contains a cleft in its structure, and the active center of this enzyme lies within this cleft (36); similar findings were also recently reported for ribonuclease (37). On the basis of this information about the structure of proteins and of retinol, we suggest that $\mathrm{RBP}$ contains a thin cleft in its tertiary structure, and that the flat retinol molecule resides within the hydrophobic interior of this cleft, with its hydroxyl group at or near the surface of the protein. Furthermore, since retinol has certain "aromatic" characteristics, and since RBP contains an unusually high content of aromatic amino acids, it is possible that the aromatic amino acid residues play an important role in the structure of the retinol-binding cleft, and in the interaction between retinol and RBP.

It was recently reported by Alvsaker, Haugli, and Laland (5) that vitamin A is present in plasma attached to the "tryptophane-rich" prealbumin. In their studies, these workers chromatographed serum on columns of Sephadex G-200 and DEAESephadex and isolated a protein fraction which was fluorescent and which contained both vitamin $A$ and prealbumin. This preparation was thus equivalent to our D preparation, which does indeed contain both prealbumin and RBP. Unfortunately, the conditions of electrophoresis which these workers then employed $(\mathrm{pH} 4.0$ for paper electrophoresis) were unsatisfactory for the separation of prealbumin and RBP, and this led them to the conclusion that the vitamin $\mathrm{A}$ in the preparation must be bound to the prealbumin.

The preliminary immunodiffusion experiments reported here demonstrated that RBP did not react with commercial antisera against whole human serum, human serum albumin, prealbumin, ceruloplasmin, or $\alpha_{1}$-acid glycoprotein. Studies of the immunologic properties of RBP and of the RBPprealbumin complex are in progress.

In plasma, RBP apparently circulates in the form of a complex, together with another, larger protein with prealbumin mobility. In our studies, the protein-protein complex remained intact during Cohn fractionation and chromatography on
Sephadex or DEAE-Sephadex columns. The complex dissociated into its two different components, however, during electrophoresis. The dissociation of the complex into separated RBP and prealbumin seemed to be a function of the electric field and not of the supporting medium used for electrophoresis, since the separation of prealbumin and RBP was observed during electrophoresis on polyacrylamide gel, paper, and Pevikon. The complex was again formed, however, by mixing together separated prealbumin and RBP. The size of the complex was estimated to be in the molecular weight range of approximately 80,000-90,000. The ability of prealbumin to complex with RBP was quite limited, since the prealbumin was readily saturated with RBP by increasing the relative amount of RBP in the mixture (Fig. 13).

From its electrophoretic and immunologic properties, the prealbumin isolated by us, which interacts with RBP, appears to be identical with the so-called "thyroxine-binding" (or "tryptophanerich") prealbumin in human plasma. This protein has been studied by several groups of investigators $(21,34,38)$, particularly with regard to its role as one of the plasma transport proteins for thyroid hormone. The molecular weight of prealbumin has been reported to be 61,000 (34) and 73,000 (21). This molecular weight range is similar to the molecular weight of the prealbumin isolated by us (as estimated by gel filtration). From the estimated molecular weights of the RBP-prealbumin complex, and of each of its components, it appears that one molecule of prealbumin can interact with one molecule of RBP to form a stable complex. The effect of the RBP-prealbumin interaction on the binding and transport of thyroid hormone by prealbumin remains to be determined. It is, of course, also possible that the prealbumin isolated here which interacts with RBP is very similar to, but not identical with, the prealbumin involved in thyroxine transport in plasma.

Retinol transport in plasma thus involves both a lipid-protein (retinol-RBP) interaction and a protein-protein (RBP-prealbumin) interaction. Each of these interactions appears to serve an important physiological role. Thus, the interaction of retinol with RBP serves to solubilize the waterinsoluble retinol molecule and to protect the un- 
stable retinol molecule against chemical degradation. The magnitude of the protective effect is indicated by the fact that retinol (bound to RBP) remains intact in whole plasma kept for several weeks at $4^{\circ} \mathrm{C}$, whereas retinol itself is highly unstable and decomposes rapidly in solution in organic solvents when exposed to traces of oxygen or to light. Similarly, the protein-protein interaction clearly serves to protect the RBP molecule, by preventing the glomerular filtration of the relatively small RBP molecule, and hence the loss of $\mathrm{RBP}$ in the urine. In addition, it is possible that the interaction of RBP with prealbumin may serve to further stabilize and protect the retinol molecule. Further studies are in progress to explore these questions.

\section{ACKNOWLEDGMENTS}

We thank Mr. T. Shiratori, Mrs. J. Vormbaum, and Miss E. Miller for expert assistance in this work. We are most grateful to Dr. R. Canfield for amino acid analyses, to Dr. H. Rosenkranz for analytical ultracentrifugal analyses, and to Dr. J. H. Morse for zonal electrophoresis and for assistance with immunologic studies. Hoffmann-La Roche, Inc., Basel, Switzerland, generously provided the retinol-15- ${ }^{14} \mathrm{C}$.

This work was supported by grant No. AM-05968 from the National Institutes of Health. Masamitsu Kanai and Amiram Raz were trainees under grant No. T1 AM-5397 from the National Institutes of Health. DeWitt S. Goodman is a Career Scientist of the Health Research Council of the City of New York under contract No. I-399.

\section{REFERENCES}

1. Krinsky, N. I., D. G. Cornwell, and J. L. Oncley. 1958. The transport of vitamin $A$ and carotenoids in human plasma. Arch. Biochem. Biophys. 73: 233.

2. Garbers, C. F., J. Gillman, and M. Peisach. 1960. The transport of vitamin A in rat serum with special reference to the occurrence of unidentified metabolites of vitamin A in the rat. Biochem. J. 75: 124.

3. Goodman, DeW. S., H. S. Huang, and T. Shiratori. 1965. Tissue distribution and metabolism of newly absorbed vitamin A in the rat. J. Lipid Res. 6: 390.

4. Glover, J., and R. J. Walker. 1964. Absorption and transport of vitamin A. Exptl. Eye Res. 3: 374.

5. Alvsaker, J. O., F. B. Haugli, and S. G. Laland. 1967. The presence of vitamin $A$ in human tryptophane-rich prealbumin. Biochem. J. 102: 362.

6. Huang, H. S., and DeW. S. Goodman. 1965. Vitamin $\mathrm{A}$ and carotenoids. I. Intestinal absorption and metabolism of ${ }^{14} \mathrm{C}$-labeled vitamin $\mathrm{A}$ alcohol and $\beta$-carotene in the rat. J. Biol. Chem. 240: 2839.

7. Gelotte, B. 1964. Fractionation of proteins peptides and amino acids by gel filtration. In New Biochemical
Separations. A. T. James and L. J. Morris, editors. D. Van Nostrand Co., Inc., London. 93.

8. Nerenberg, S. T. 1966. Electrophoresis. A Practical Laboratory Manual. F. A. Davis Co., Philadelphia.

9. Jovin, T., A. Chrambach, and M. A. Naughton. 1964. An apparatus for preparative temperature-regulated polyacrylamide gel electrophoresis. Anal. Biochem. 9: 351 .

10. Oppenheimer, J. H., and R. R. Tavernetti. 1962. Displacement of thyroxine from human thyroxine-binding globulin by analogues of hydantoin. Steric aspects of the thyroxine-binding site. J. Clin. Invest. 41: 2213.

11. Müller-Eberhard, H. J. 1960. A new supporting medium for preparative electrophoresis. Scand. J. Clin. Lab. Invest. 12: 33.

12. Schachman, H. K. 1957. Ultracentrifugation, diffusion, and viscometry. In Methods in Enzymology. S. P. Colowick and N. O. Kaplan, editors. Academic Press Inc., New York. 4: 32.

13. Spackman, D. H., W. H. Stein, and S. Moore. 1958. Automatic recording apparatus for use in the chromatography of amino acids. Anal. Chem. 30: 1190.

14. Goodwin, T. W., and R. A. Morton. 1946. The spectrophotometric determination of tyrosine and tryptophane in proteins. Biochem. J. 40: 628 .

15. Ouchterlony, ర. 1962. Diffusion-in-gel methods for immunological analysis. In Progress in Allergy. P. Kallos and B. H. Waksman, editors. S. Karger, Basel. 6: 30 .

16. Cohn, E. J., F. R. N. Gurd, D. M. Surgenor, B. A. Barnes, R. K. Brown, G. Derouaux, J. M. Gillespie, F. W. Kahnt, W. F. Lever, C. H. Liu, D. Mittelman, R. F. Mouton, K. Schmid, and E. Uroma. 1950. A system for the separation of the components of human blood: quantitative procedures for the separation of the protein components of human plasma. $J$. Am. Chem. Soc. 72: 465.

17. Havel, R. J., H. A. Eder, and J. H. Bragdon. 1955. The distribution and chemical composition of ultracentrifugally separated lipoproteins in human serum. J. Clin. Invest. 34: 1345.

18. Lowry, O. H., N. J. Rosebrough, A. L. Farr, and R. J. Randall. 1951. Protein measurement with the Folin phenol reagent. J. Biol. Chem. 193: 265.

19. Goodman, DeW. S., and T. Shiratori. 1964. Fatty acid composition of human plasma lipoprotein fractions. J. Lipid Res. 5: 307.

20. Whitaker, J. R. 1963. Determination of molecular weights of proteins by gel filtration on Sephadex. Anal. Chem. 35: 1950.

21. Oppenheimer, J. H., M. I. Surks, J. C. Smith, and R. Squef. 1965. Isolation and characterization of human thyroxine-binding prealbumin. J. Biol. Chem. 240: 173.

22. Schmid, K., J. P. Binette, K. Tokita, L. Moroz, and H. Yoshizake. 1964. The polymorphic forms of $\alpha_{1}$-acid glycoprotein of normal Caucasian individuals. J. Clin. Invest. 43: 2347.

Vitamin A Transport in Human Plasma 2043 
23. Fredrickson, D. S., and R. S. Gordon, Jr. 1958. Transport of fatty acids. Physiol. Rev. 38: 585.

24. Switzer, S., and H. A. Eder. 1965. Transport of lysolecithin by albumin in human and rat plasma. J. Lipid Res. 6: 506.

25. Fredrickson, D. S., R. I. Levy, and R. S. Lees. 1967. Fat transport in lipoproteins-An integrated approach to mechanisms and disorders. New Engl. J. Med. 276: 34.

26. Alaupovic, P., S. S. Sanbar, R. H. Furman, M. L. Sullivan, and S. L. Walraven. 1966. Studies of the composition and structure of serum lipoproteins. Isolation and characterization of very high density lipoproteins of human serum. Biochemistry. 5: 4044.

27. Scanu, A., and W. L. Hughes. 1962. Further characterization of the human serum D 1.063-1.21, $\alpha_{1}$-lipoprotein. J. Clin. Invest. 41: 1681.

28. Shore, V., and B. Shore. 1962. The protein subunit of human serum lipoproteins of density 1.125-1.200 gram $/ \mathrm{ml}$. Biochem. Biophys. Res. Comm. 9: 455.

29. Levy, R. I., and D. S. Fredrickson. 1965. Heterogeneity of plasma high density lipoproteins. J. Clin. Invest. 44: 426.

30. Margolis, S., and R. G. Langdon. 1966. Studies on human serum $\beta_{1}$-lipoprotein. I. Amino acid composition. J. Biol. Chem. 241 : 469.

31. Scanu, A., and J. L. Granda. 1966. Effects of ultracentrifugation on the human serum high-density $(1.063<\rho<1.21 \mathrm{~g} / \mathrm{ml})$ lipoprotein. Biochemistry. 5: 446.
32. Granda, J. L., and A. Scanu. 1966. Solubilization and properties of the apoproteins of the very low- and low-density lipoproteins of human serum. Biochemistry. 5 : 3301.

33. Shore, V., and B. Shore. 1967. Some physical and chemical studies on the protein moiety of a high density $(1.126-1.195 \mathrm{~g} / \mathrm{ml})$ lipoprotein fraction of human serum. Biochemistry. 6: 1962.

34. Schultze, H. E., M. Schönenberger, and G. Schwick. 1956. Über ein Präalbumin des menschlichen Serums. Biochem. Z. 328: 267.

35. Kendrew, J. C. 1963. Myoglobin and the structure of proteins. Science. 139: 1259.

36. Blake, C. C. F., L. N. Johnson, G. A. Mair, A. C. T. North, D. C. Phillips, and V. R. Sarma. 1967. Crystallographic studies of the activity of hen egg-white lysozyme. Proc. Roy. Soc. London Ser. B. 167: 378.

37. Kartha, G., J. Bello, and D. Harker. 1967. Tertiary structure of ribonuclease. Nature. 213: 862 .

38. Purdy, R. H., K. A. Woeber, M. T. Holloway, and S. H. Ingbar. 1965. Preparation of crystalline thyroxine-binding prealbumin from human plasma. Biochemistry. $4: 1888$.

39. Kanai, M., and DeW. S. Goodman. 1967. Retinol transport protein: a "new" plasma lipoprotein. Abstracts of the Seventh International Congress of Biochemistry, Tokyo, Japan. 1056.

40. Raz, A., M. Kanai, and DeW. S. Goodman. 1968. Retinol binding protein (RBP) : a newly-recognized plasma lipoprotein. Federation Proc. 27: 594. (Abstr.) 